\title{
USE OF GROUND-PENETRATING RADAR FOR WATER-TABLE MAPPING, BREWSTER AND HARWICH, MASSACHUSETTS
}

by David G. Johnson

U.S. GEOLOGICAL SURVEY

Water-Resources Investigations Report 90-4086

Prepared in cooperation with the

MASSACHUSETTS DEPARTMENT OF ENVIRONMENTAL PROTECTION, DIVISION OF WATER POLLUTION CONTROL, AND THE TOWNS OF BREWSTER AND HARWICH, MASSACHUSETTS

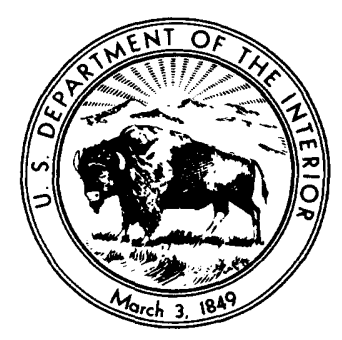

Marlborough, Massachusetts 1992 


\section{U.S. DEPARTMENT OF THE INTERIOR}

MANUEL LUJAN, JR., Secretary

\section{U.S. GEOLOGICAL SURVEY}

Dallas L. Peck, Director

For additional information, write to:

District Chief

Massachusetts - Rhode Island District

U.S. Geological Survey

Water Resources Division

28 Lord Rd., Suite 280

Marlborough, MA 01752
Copies of this report can be purchased from: Books and Open-File Reports Section U.S. Geological Survey

Federal Center

Box 25425, Building 810

Denver, CO 80225 


\section{CONTENTS}

Page

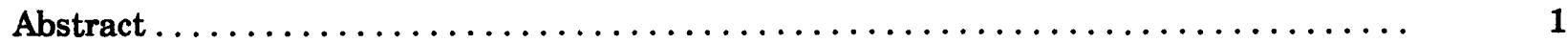

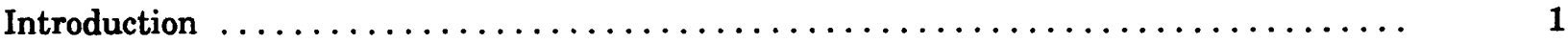

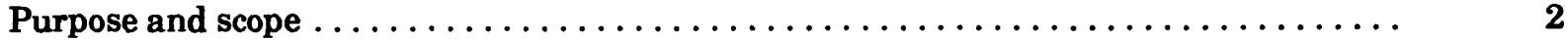

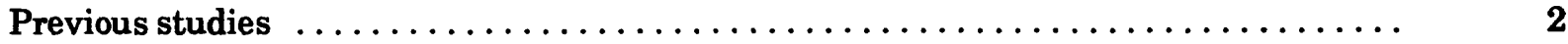

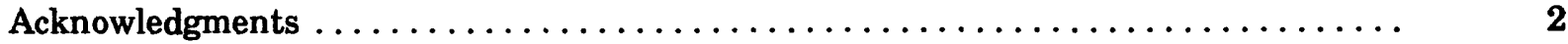

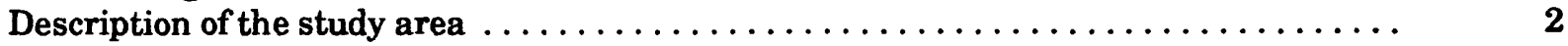

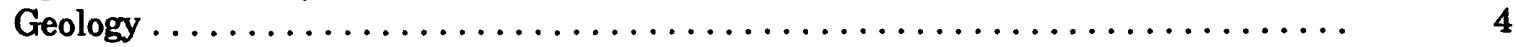

Hydrology . . . . . . . . .

Operation of the ground-penetrating radar system $\ldots \ldots \ldots \ldots \ldots \ldots \ldots \ldots \ldots \ldots \ldots \ldots . \ldots \ldots$

Ground-penetrating radar equipment $\ldots \ldots \ldots \ldots \ldots \ldots \ldots \ldots \ldots \ldots \ldots \ldots \ldots \ldots \ldots \ldots \ldots \ldots \ldots \ldots \ldots \ldots$

Ground-penetrating radar surveys $\ldots \ldots \ldots \ldots \ldots \ldots \ldots \ldots \ldots \ldots \ldots \ldots \ldots \ldots \ldots \ldots \ldots \ldots \ldots \ldots \ldots$

Interpretation of the ground-penetrating radar record $\ldots \ldots \ldots \ldots \ldots \ldots \ldots \ldots \ldots \ldots \ldots . \ldots$

Depth of penetration of the ground-penetrating radar signal $\ldots \ldots \ldots \ldots \ldots \ldots \ldots \ldots \ldots$

Identification of the water-table reflector $\ldots \ldots \ldots \ldots \ldots \ldots \ldots \ldots \ldots \ldots \ldots \ldots \ldots \ldots$

Signal-propagation velocities in unsaturated materials $\ldots \ldots \ldots \ldots \ldots \ldots \ldots \ldots \ldots \ldots$

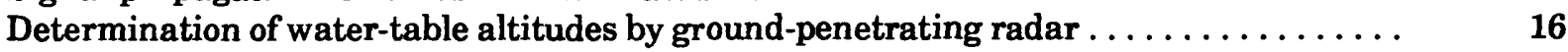

Comparison of ground-penetrating radar and seismic refraction $\ldots \ldots \ldots \ldots \ldots \ldots \ldots \quad 18$

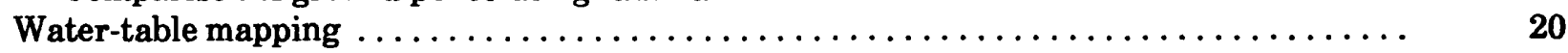

Determining zones of contribution to pumped wells $\ldots \ldots \ldots \ldots \ldots \ldots \ldots \ldots \ldots \ldots \ldots$

Determining water-table configuration near waste-disposal areas $\ldots \ldots \ldots \ldots \ldots \ldots \ldots \quad 22$

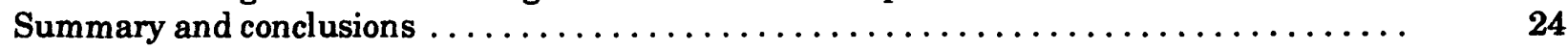

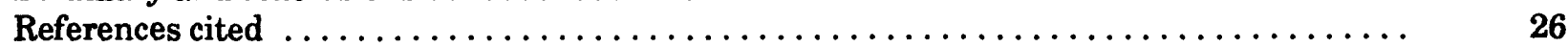

\section{ILLUSTRATIONS}

Figure $\quad$ 1. Map showing location of study area and surficial deposits ............. 3

2. Graph showing median end-of-month water levels for selected observation wells ... $\quad 5$

3. Graphs showing median end-of-month water levels for observation well HJW 145 and median monthly mean streamflow for the Herring River for the period $1975-86 \ldots \ldots \ldots \ldots \ldots \ldots \ldots \ldots \ldots \ldots \ldots \ldots \ldots \ldots \ldots$

4. Hydrologic section A-A' through the aquifer between Cape Cod Bay and

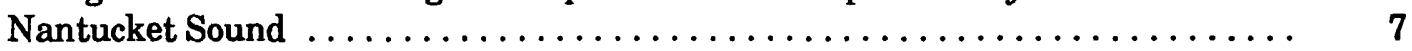

5. Photograph of ground-penetrating radar equipment $\ldots \ldots \ldots \ldots \ldots \ldots \ldots \ldots \ldots$

6. Diagram of appearance of a radar signal on a cathode ray tube screen and on a graphic recorder $\ldots \ldots \ldots \ldots \ldots \ldots \ldots \ldots \ldots \ldots \ldots \ldots \ldots \ldots \ldots$

7. Diagram of radar record and calculation of average propagation velocity of radar signal in the unsaturated zone $\ldots \ldots \ldots \ldots \ldots \ldots \ldots \ldots \ldots \ldots$ 


\section{ILLUSTRATIONS--Continued}

8. Diagram of radar record and calculation of average propagation of radar signal velocity in the unsaturated zone using a stationary

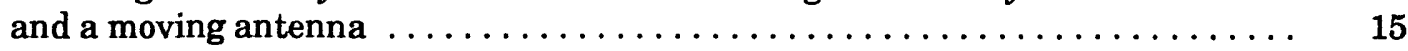

9. Graph showing relation between depth to water and two-way travel time ....... 16

10. Diagram of a sample ground-penetrating radar record showing a water-table profile and the record interpretation $\ldots \ldots \ldots \ldots \ldots \ldots \ldots \ldots \ldots \ldots \ldots$

11. Graph showing water-table profiles determined using ground-penetrating radar and seismic-refraction methods, and water levels

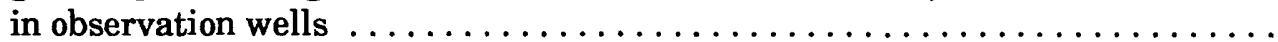

12. Map showing generalized thickness of the unsaturated zone Harwich and Brewster, Massachusetts ..................... 23

13. Map showing configuration and altitude of the water table in the vicinity of the Harwich landfill, September, 1986

\section{TABLES}

Table

1. Altitude of water levels in observation wells used to determine vertical flow

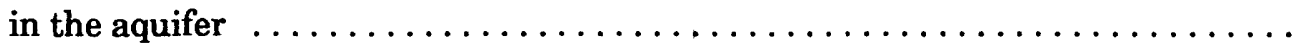

2. Measured water-table altitudes, and water-table altitude calculated by ground-penetrating radar and seismic refraction at selected observation wells

\section{PLATE}

[located in back pocket]

Plate 1. Water-table map of Brewster and Harwich, Massachusetts, September 21 through October 22, 1987 


\section{CONVERSION FACTORS AND VERTICAL DATUM}

\begin{tabular}{|c|c|c|}
\hline Multiply & By & To obtain \\
\hline \multicolumn{3}{|c|}{ Length } \\
\hline $\begin{array}{l}\text { inch (in.) } \\
\text { foot (ft) } \\
\text { mile (mi) }\end{array}$ & $\begin{array}{l}25.4 \\
0.3048 \\
1.609\end{array}$ & $\begin{array}{l}\text { millimeter } \\
\text { meter } \\
\text { kilometer }\end{array}$ \\
\hline \multicolumn{3}{|c|}{ Area } \\
\hline $\begin{array}{l}\text { square foot }\left(\mathrm{ft}^{2}\right) \\
\text { square mile }\left(\mathrm{mi}^{2}\right)\end{array}$ & $\begin{array}{l}0.09290 \\
2.59\end{array}$ & $\begin{array}{l}\text { square meter } \\
\text { square kilometer }\end{array}$ \\
\hline \multicolumn{3}{|c|}{ Flow } \\
\hline $\begin{array}{l}\text { cubic foot per second }\left(\mathrm{ft}^{3} / \mathrm{s}\right) \\
\text { mile per hour }(\mathrm{mi} / \mathrm{h}) \\
\text { million gallons per day }(\mathrm{Mgal} / \mathrm{d})\end{array}$ & $\begin{array}{l}0.02832 \\
1.609 \\
0.04381\end{array}$ & $\begin{array}{l}\text { cubic meter per second } \\
\text { kilometer per hour } \\
\text { cubic meter per second }\end{array}$ \\
\hline \multicolumn{3}{|c|}{ Density } \\
\hline $\begin{array}{l}\text { pounds per cubic foot } \\
\left(\mathrm{lb} / \mathrm{ft}^{3}\right)\end{array}$ & 0.01602 & grams per cubic centimeter \\
\hline
\end{tabular}

Sea level: In this report "sea level" refers to the National Geodetic Vertical datum of 1929--a geodetic datum derived from a general adjustment of the first-order level nets of both the United States and Canada, formerly called Sea Level Datum of 1929. 


\title{
Use of Ground-Penetrating Radar for Water-Table Mapping, Brewster and Harwich, Massachusetts
}

\author{
By David G. Johnson
}

\begin{abstract}
More than 125 miles of continuous ground-penetrating radar profiles of the sand and gravel aquifer on Cape Cod, Massachusetts, were made in the towns of Brew. ster and Harwich. Penetration of the radar signal ranged from less than 3 feet in areas containing clay near the surface, to more than 95 feet in clay-free sand and gravel. About 60 percent of the radar profiles showed water-table images that were easily identified on the graphic record.

Depths to water were calculated from the radar records using an average signal velocity of 0.45 feet per nanosecond in the unsaturated zone. Comparison of depths to water derived using ground-penetrating radar with the altitude of water levels measured in wells and ponds at 85 sites showed an average difference of about 7 percent (1.8 feet) with standard deviation of 6.4 percent (1.8 feet). Additionally, good agreement was achieved between water-table altitudes calculated using ground-penetrating radar and seismic-refraction methods with altitudes determined at selected observation wells.
\end{abstract}

Ground-penetrating radar was used in conjunction with water levels measured at ponds and wells to construct a water-table map with 2-foot contours in the 45-square mile area of Brewster and Harwich. The radar proved unsuccessful in determining zones of contribution to pumping wells, but provided sufficient water-table information to delineate a ground-water mound at a septage disposal bed and steep water-table gradients toward a stream near the Harwich landfill.

\section{NNTRODUCTION}

As water demand and the amount of disposed waste increase with population, effective land-use planning and management is needed to protect ground-water quality. Maintenance of ground-water quality is especially important on Cape Cod, where the principal aquifer is a sole-source water-table aquifer that is directly recharged from land surface.

Generally, directions of ground-water flow can be determined from water-table maps, which can be constructed from water levels measured at ponds and wells. Water levels are generally site specific and interpretations between measuring points must be inferred. To produce detailed water-table maps, many wells are typically drilled in areas of interest to refine the accuracy of the maps. However, because well drilling is an expensive and, often, slow process, alternative methods are needed to obtain reliable watertable information.

One alternative method using ground-penetrating radar (GPR) has been used successfully to determine depth to water from the land surface in small areas with homogeneous surficial geology (Collins and Doolittle, 1987; Shih and others, 1986; Wright and others, 1984; Ulriksen, 1982). However, there remained a 
need to test the applicability of the method over large areas with diverse surficial geology.

In 1986, the U.S. Geological Survey (USGS), in cooperation with the Massachusetts Department of Environmental Protection, Division of Water Pollution Control, and the towns of Brewster and Harwich, Massachusetts, began a water-table mapping program designed to answer several questions: Can GPR provide continuous water-table profiles in areas of Cape Cod where surficial geology is diverse? If so, can this data be used to determine water-table altitudes and to improve the precision of water-table maps? Can GPR be used to determine water-table altitudes in areas that contain no water-table ponds or observation wells? And finally, can GPR be used to determine zones of contribution to pumped wells and the approximate direction of ground-water flow at waste-disposal areas?

\section{Purpose and Scope}

This report describes the use of GPR for determining water-table altitudes in the aquifer in the towns of Brewster and Harwich, Massachusetts. Discussions of the hydrogeology of the area, the GPR equipment, and survey techniques used in this study are provided. Special attention is given to interpreting the GPR record, depth of penetration of the GPR signal, proper identification of the top of the saturated zone, and estimating or calculating the velocity of the GPR signal in the unsaturated zone. The GPR results are compared to data from ponds and wells and to results obtained using seismic-refraction. In addition, the use of GPR for determining zones of contribution to pumped wells, and direction of ground-water flow near waste-disposal areas is described.

\section{Previous Studies}

Studies of the Cape Cod aquifer by the USGS (Frimpter, 1973; Frimpter and Gay, 1979; Guswa and LeBlanc, 1985; LeBlanc and others, 1986) and Horsley (1982), describe the ground-water-flow system and provide some information about ground-water quality. A water-table map with a contour interval of $10 \mathrm{ft}$ was produced by LeBlanc and others (1986). Although this map indicates the general direction of horizontal ground-water flow on the Cape, it does not contain sufficient information for detailed delineation of zones of contribution to wells or for determination of de- tailed ground-water-flow patterns near waste-disposal areas.

Two studies described the use of GPR in the outwash plain on Cape Cod. In the Town of Falmouth, in southwestern Cape Cod, Wright and others (1984) used GPR to study an underground sewage plume and found GPR to be ineffective for detecting the sewage plume, but effective in detecting the water table and subsurface stratigraphic features. In the Town of Mashpee, also in southwestern Cape Cod, Shih and others (1986) used GPR to measure depth to the water table at depths of up to $36 \mathrm{ft}$ in well-drained, coarsetextured, upland soils, and 5 to $8 \mathrm{ft}$ in poorly drained, coarse-textured, coastal plain soils.

\section{Acknowledgments}

The author thanks the many individuals who have kindly provided assistance and information during this study. Particular thanks are given to the following individuals from town agencies: Robert Zontini and Paul Hicks, Brewster Water Department; Allan Tkaczyk and Ken Harwood, Brewster Department of Public Works; Chris Zocca and Bruce Cahoon, Harwich Water Department; Martin Moran, Harwich Engineering Department; Jeffrey Hamel, Wehran Engineering; and Nancy Davis, GZA Geoenvironmental, Inc..

\section{Description of the Study Area}

The study was conducted in the $45-\mathrm{mi}^{2}$ area of the towns of Brewster and Harwich (fig. 1). The combined year-round population is about 16,000 , and increases greatly during the summer because of an influx of seasonal residents and tourists. Although greatest along the shorelines, development is proceeding rapidly in inland forested areas and around fresh-water ponds.

The study area is characterized by gently rolling hills and plains that are forested with pine and oak trees and contain scattered fresh-water ponds. A high ridge runs from the southwest to northeast near the center of the study area. The southeastern side of the ridge slopes gently to Nantucket Sound in Harwich. The northwestern side slopes more steeply to Cape Cod Bay in Brewster. Elevations range from about $150 \mathrm{ft}$ in the eastern part of Brewster to sea level along the coasts. Wetland areas are present along the lower 


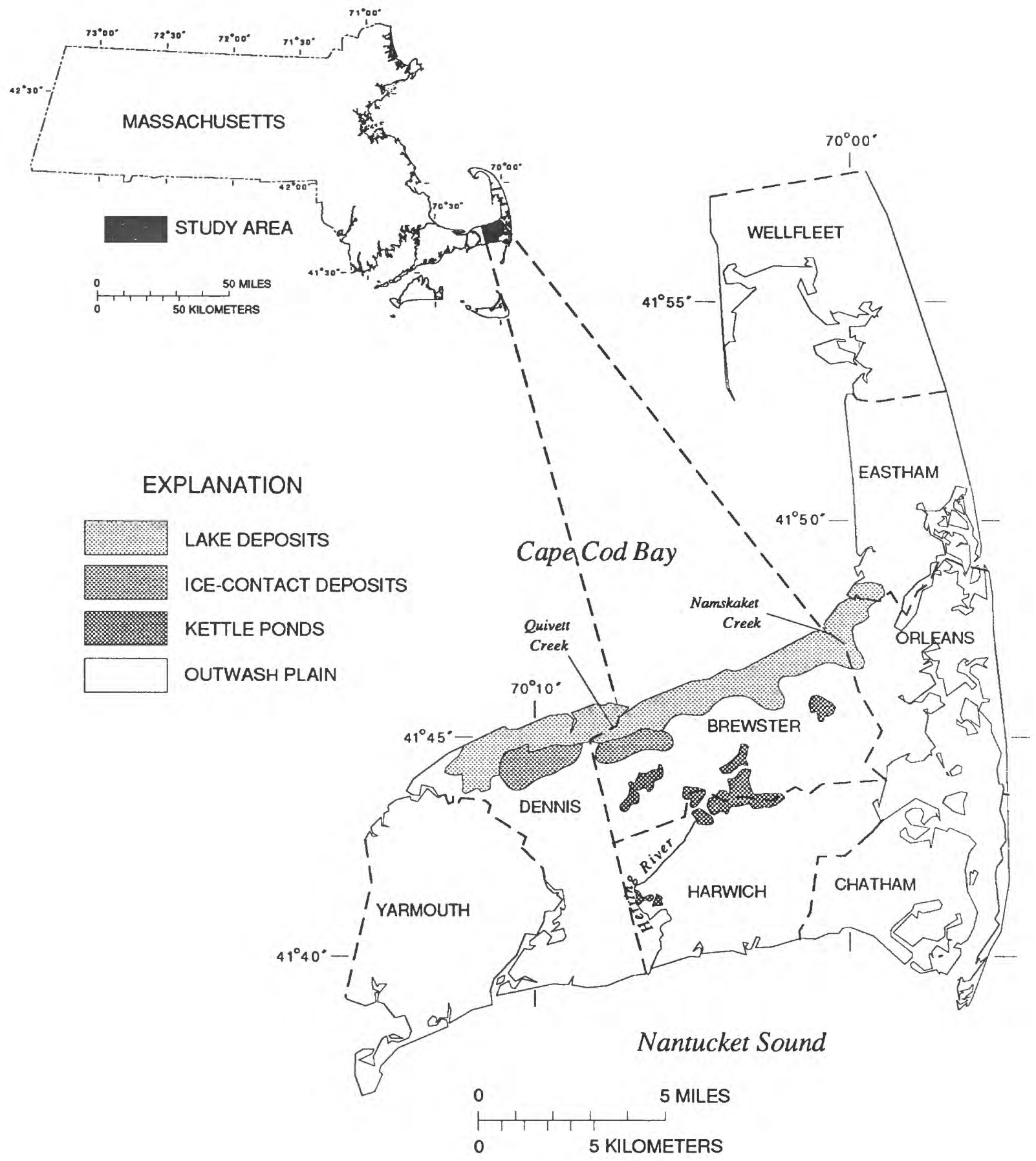

Figure 1.--Location of study area and surficial deposits. 
reaches of Herring River in Harwich, and along Quivett Creek and Namskaket Creek, which form the northwestern and northeastern town lines, respectively, of Brewster (fig. 1).

\section{Geology}

In the study area, bedrock ranges in altitude from more than $500 \mathrm{ft}$ below sea level along Nantucket Sound to less than $300 \mathrm{ft}$ below sea level near Cape Cod Bay (Oldale and Tuttle, 1965). The bedrock is overlain by stratified drift, which is mainly composed of sand, with some gravel, silt, and clay, and, locally, till. These sediments were deposited within the last 25,000 years by the advance and retreat of a continental glacier. The stratified-drift deposits form a southsloping glacial outwash plain in most of Harwich and in the southern part of Brewster (fig. 1). The outwash plain was deposited by glacial meltwater streams and is composed mostly of stratified sand and gravel, but includes lenses of silt, till, and some boulders.

The many ponds and hills near the center of the study area are kettles and kames that were formed from melting ice. A kettle is a depression in the glacial deposits that was originally filled with ice, which melted. A kame is a knoll or hill of glacial sediment that originally filled a hole in the ice sheet. Some kettles and kames in the northern part of the outwash plain resulted from the deposition of glacial outwash over and around a thin, uneven, stagnant wedge of ice (Oldale, 1981). As this buried ice later melted, kettle zones formed in the overlying outwash to impart the irregular topography of this area.

Glacial materials in the northwestern corner of Brewster are ice-contact deposits (fig. 1), which were deposited near or adjacent to glacial ice. These deposits are highly variable in composition and include lenses of till, well-sorted and stratified sand and gravel, stratified silt and clay, and some boulders.

As the glacial ice retreated to the north, a glacial lake formed between the ice front and the ice-contact and outwash deposits. Clay, silt, and fine sand were deposited as deltas and lake-bottom deposits in the glacial lake (Oldale, 1981). The locations of the outwash plain, larger kettle ponds, ice-contact deposits, and glacial-lake sediments are shown in figure 1.

\section{Hydrology}

The long-term annual precipitation at the National Oceanic and Atmospheric Administration (NOAA) station in Chatham averaged $47 \mathrm{in} / \mathrm{yr}$ for the period 1971-86. During this study, May 1986 through October 1987 , precipitation averaged $56 \mathrm{in} / \mathrm{yr}$, according to measurements made at the Harwich Water Department, located approximately $1 \mathrm{mi}$ northwest of the NOAA station. This deviation in rainfall amount indicates that the study occurred during a period of above-average precipitation.

The USGS, in cooperation with the Cape Cod Commission and the Massachusetts Office of Water Resources, maintains a Capewide network of observation wells to monitor ground-water levels. Six wells in this network are located in the study area. Monthly waterlevel readings, have been made since 1962 at Brewster wells BMW 21 and BMW 22. Since October 1975, monthly water-level measurements also have been made at Brewster well BMW 45 and Harwich well HJW 145, and bimonthly measurements have been made at Brewster well BMW 44 and Harwich well HJW 141 (Letty, 1984). Locations of these observation wells are shown on plate 1.

Median end-of-month water levels at four of these wells (fig. 2) show that the highest ground-water levels most commonly occurred from mid-winter to late spring and the lowest levels occurred in the fall. This range in water levels is attributed to seasonal variation in recharge (LeBlanc and others, 1986). Most recharge generally occurs during late fall, winter, and spring when plants are least active and evapotranspiration rates are low. During the summer, water demand by vegetation exceeds the replenishment of soil moisture by precipitation, whereupon moisture in the soil zone becomes depleted. Soil moisture is replenished in the fall before recharge begins. Annual fluctuations at the six long-term observation wells ranged from a maximum of $6.5 \mathrm{ft}$ at BMW 21, to a minimum of $3.6 \mathrm{ft}$ at BMW 45 .

These seasonal and long-term water-level fluctuations cause changes in the altitude and shape of the water table in Harwich and Brewster. Because the water-table maps prepared as a product of this study represents a period from September 21 through October 22, 1987, the September 1987 end-of-month water levels were compared to the medians of monthly water levels in the long-term observation wells. From this comparison, it is estimated that the water-table map 


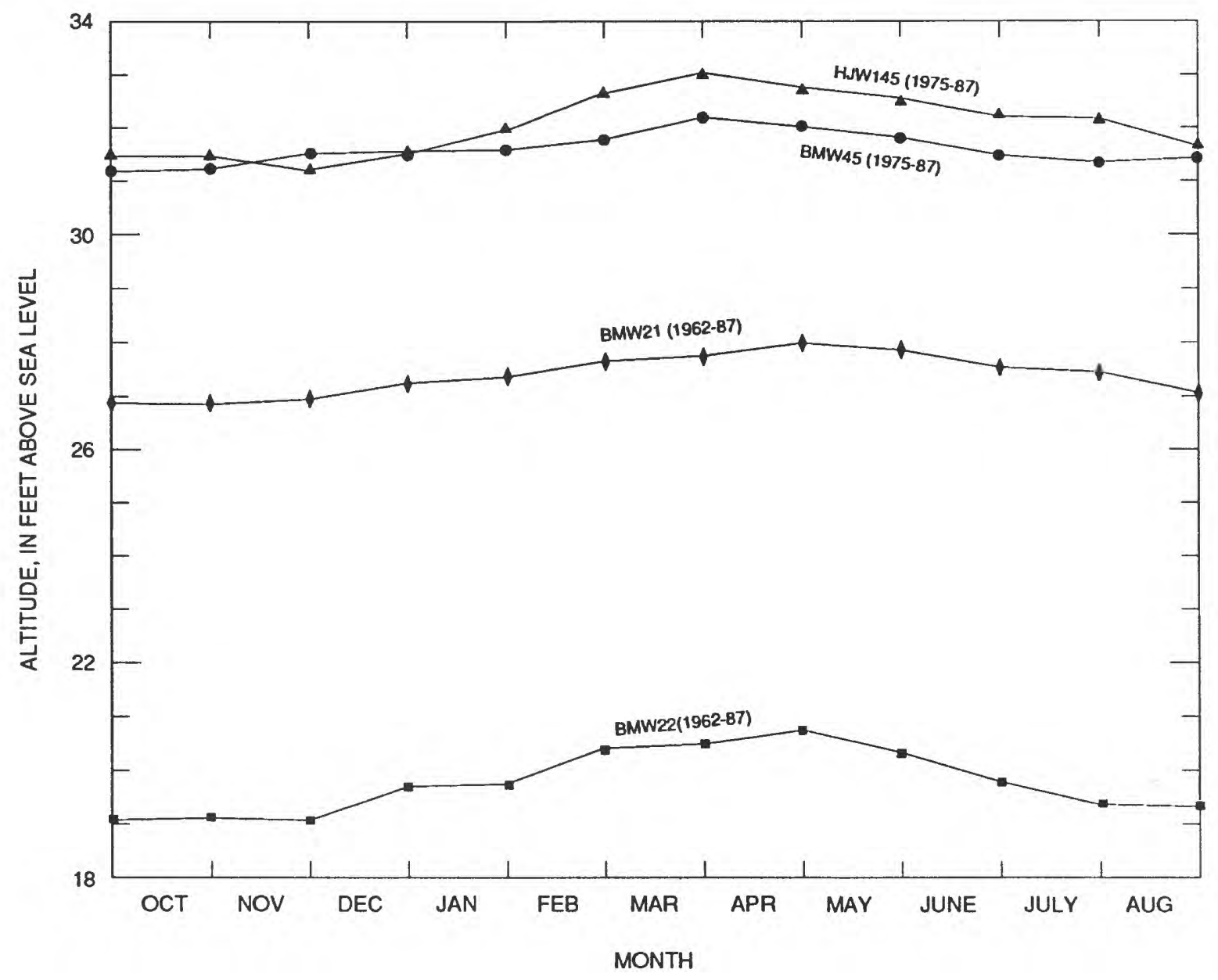

Figure 2.--Median end-of-month water levels for selected observation wells.

represents a condition in which the water table is essentially the same shape, but slightly higher than, the median water table. The difference is greatest, about $3 / 4$ feet, at the high points on the water table and decreases to no change at the shorelines of Cape Cod Bay, Nantucket Sound, and other tidal-water bodies.

Herring River, one of the few perennial streams in the study area, flows from Hinckley's Pond through west Harwich into Nantucket Sound (pl. 1). A hydrograph of the median of the monthly mean streamflow for the Herring River since 1975 shows the same trend as the median month-end ground-water level in observation well HJW 145 (fig. 3). This correlation was expected because the gradient and direction of ground-water flow in the vicinity of the river indicate that the flow in the river depends on discharge from the kettle hole pond and from ground water. The higher the water table, the greater the ground-water discharge into the stream. The well, which is 45-ft deep and screened in medium sand, is located about $1,500 \mathrm{ft}$ to the west of the river.

Kettle ponds throughout the study area reflect ground-water levels, except where water in the pond is perched above the water table by low-permeability layers of silt or clay, or where pond outlets artificially lower the water levels of ponds. Perched water is particularly common in northern Brewster because of the presence of silt and clay lake deposits at shallow depths. 

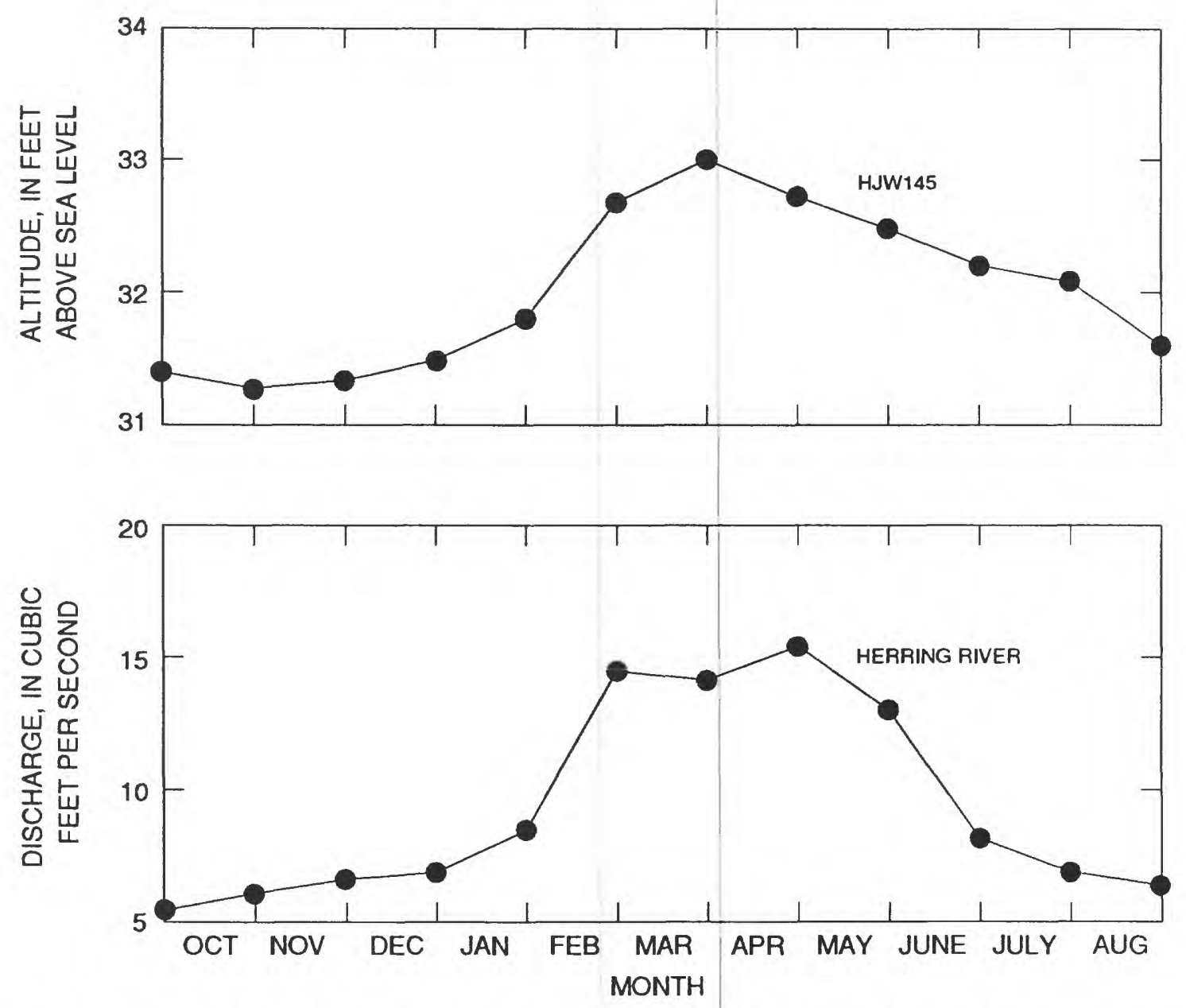

Figure 3.--Median end-of-month water levels for observation well HJW 145 and median monthly mean streamflow for the Herring River for the period 1975-86.

To provide information on the vertical component of ground-water flow within the upper $100 \mathrm{ft}$ of the saturated zone, hydraulic-head was measured in six sets of observation wells constructed along a line trending approximately from north to south in Brewster and Harwich. Each set of wells consisted of a shallow well for observing water-table fluctuations and one or two piezometers screened at 50 to $100 \mathrm{ft}$ below the top of the water table or at the top of the shallowest lens of silt or clay. In addition, a GPR survey line was run 500 to $2,500 \mathrm{ft}$ west of the six sets of observation wells to provide continuous water-table profile along the north-south line.

Using water-table altitudes from nine wells screened near the water table (six from the sets of wells and three single wells), 35 water-table altitudes derived using GPR, and head measurements from the deep piezometers at the six sets of observation wells, a cross section (A-A', plate 1 ) showing components of flow in the aquifer between Cape Cod Bay and Nantucket Sound was constructed (fig. 4). All the water-level data used to prepare this cross section was collected during October 1987.

The vertical component of ground-water flow in the upper $100 \mathrm{ft}$ of the aquifer was downward in the central uplands located north and south of Long Pond, upward in the vicinity of the coastlines, and upward in the immediate vicinity of Long Pond. This description of the general vertical flow component is probably representative of average conditions and is consistent with the general flow theory for Cape Cod (LeBlanc and others, 1986). Because the vertical and horizontal components of ground-water flow in the aquifer vary seasonally in response to recharge and withdrawals, the flow system may vary slightly. Comparison of water-level measurements made at each of the wells during March, May, June, September, October, and December, 1987 show some of the variation (table 1). 


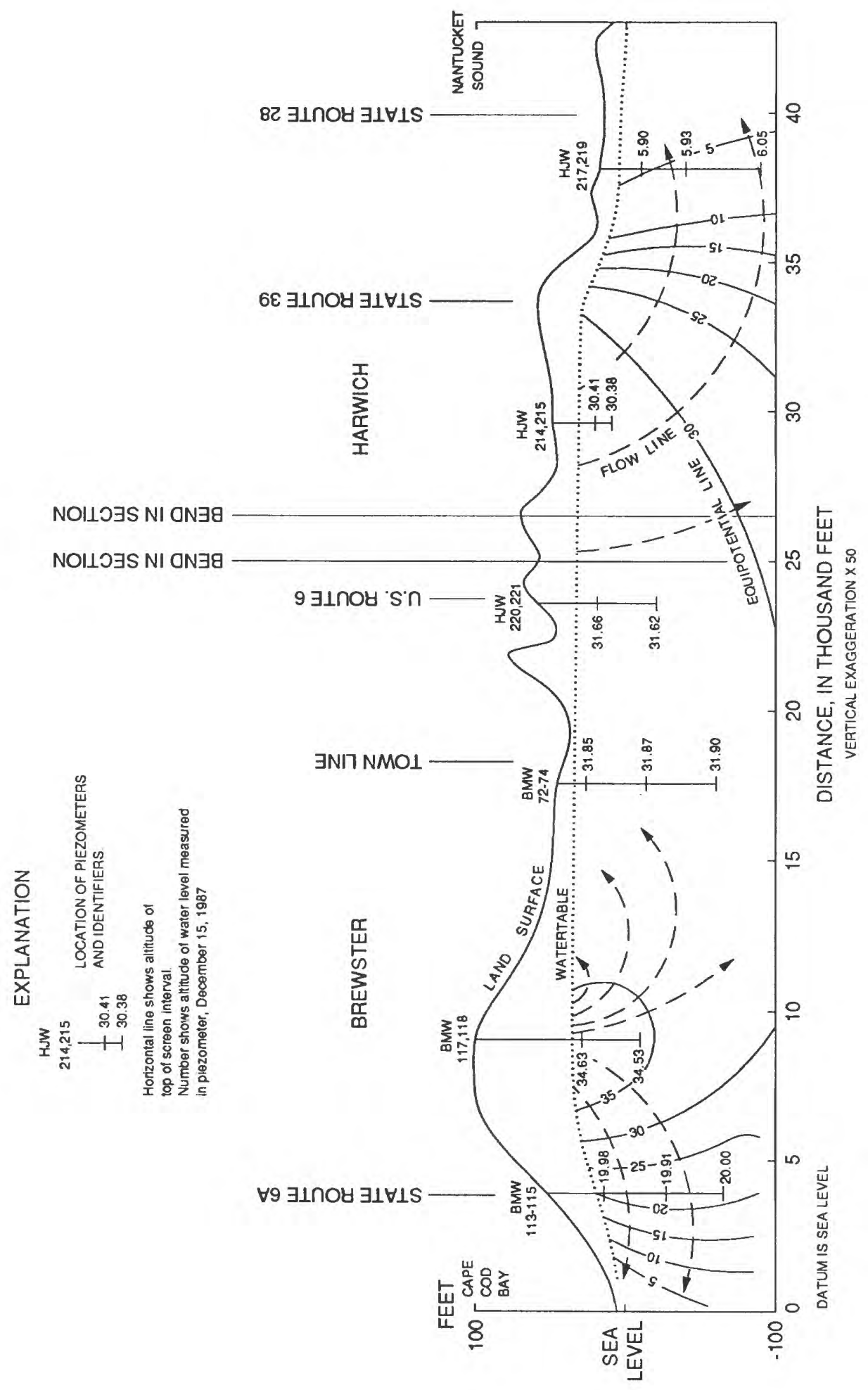

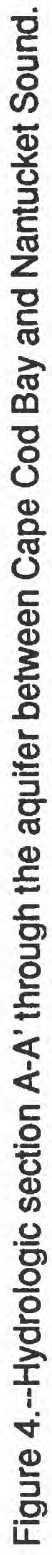




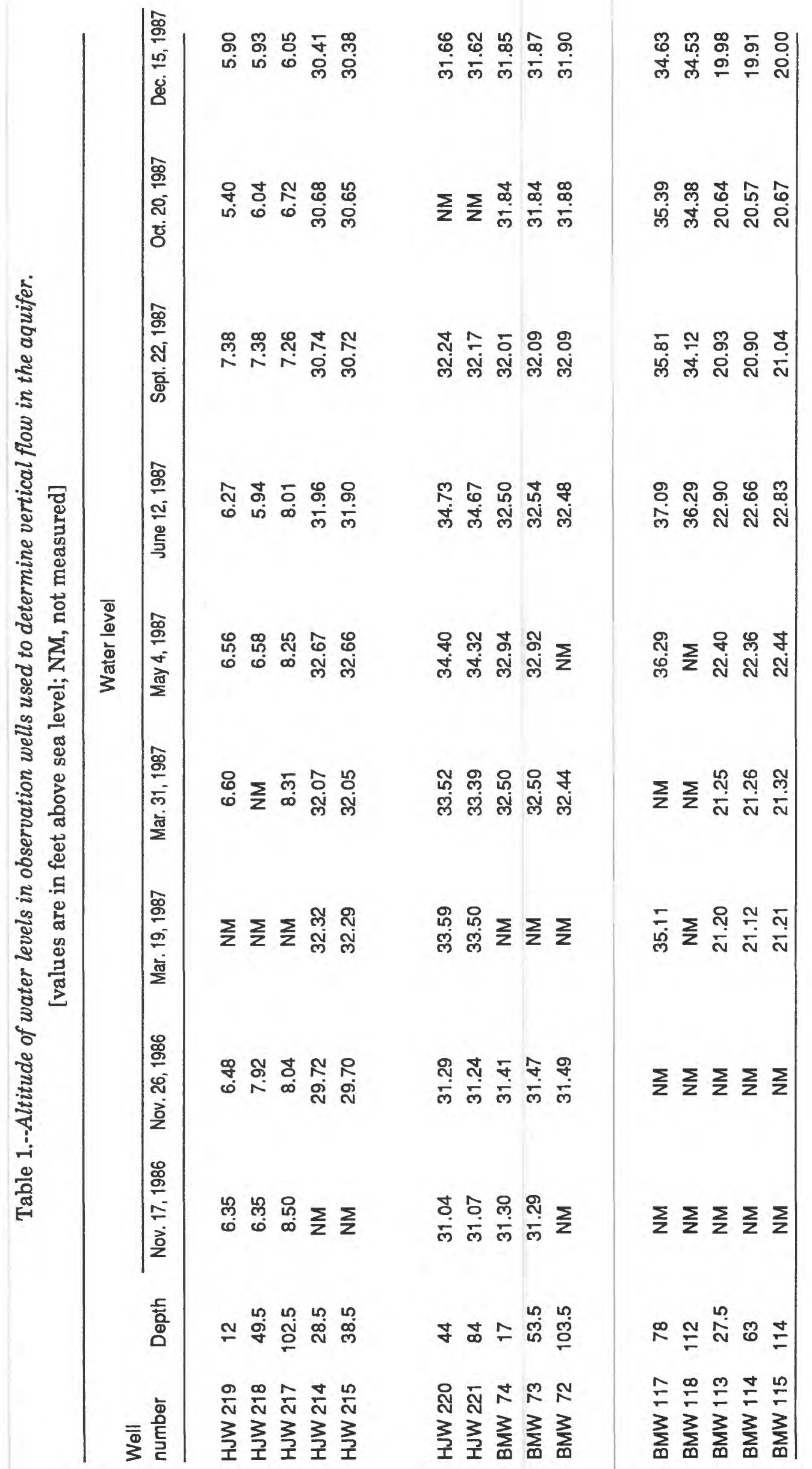


Wells HJW 217-219 are at the northern edge of a cranberry bog that is irrigated with water pumped from a well approximately $1,000 \mathrm{ft}$ to the south. The vertical component of ground-water flow at this site was upward during five of the six measurements, indicating ground-water discharge to the bog. The September measurements indicated a slight downward flow component, which was attributed to recharge from a 3-inch rainfall that occurred 3 days prior to the September measurement.

All measurements at each of the three pairs of wells located in the upland areas, HJW 214-215, HJW 220221 , and BMW 117-118, indicated the direction of the vertical flow component was downward. Only two wells were drilled at each of these sites because silt and clay were found while drilling at these sites. The vertical and horizontal extent of the silt and clay is unknown. The silt and clay may be a continuous confining layer, or a series of lenses, either of which could distort the regional ground-water flow patterns.

The direction of ground-water flow, as indicated by measurements at wells BMW 72-74, located on the northwestern side of Long Pond, varied with seasonal recharge rates and pond level changes. Measurements made during March and May 1987 indicated a slight downward flow component from the pond to the aquifer, a transition in June, and upward flow to discharge into Long Pond in September, October, and December 1987.

The vertical direction component of ground-water flow at the wells nearest Cape Cod Bay, BMW 113-115, was generally upward, but near an influent stream, a local downward component of flow was observed.

\section{OPERATION OF THE GROUND- PENETRATING RADAR SYSTEM}

\section{Ground-Penetrating Radar Equipment}

The GPR equipment used in this study consisted of an antenna to transmit and receive signals, a control unit to process signals, a graphic recorder to display radar data, and an analog tape recorder to store, process, and play back data (fig. 5). Two antennas, with nominal center frequencies of $300-\mathrm{MHz}$ (megahertz) and $80-\mathrm{MHz}$, respectively, were used.

Principles of operation of the GPR system are similar to those of conventional aircraft and marine surveil- lance radar. An antenna transmits short pulses of high frequency electromagnetic energy into the ground. Whenever a change in electrical properties is encountered at a subsurface interface, some of the transmitted energy is reflected back to the surface while the remainder continues into the earth. Subsurface changes in electrical properties are primarily attributed to differences in bulk density and (or) water content in the ground (Olhoeft and Capron, 1986).

Energy reflected from subsurface interfaces was received and amplified by the same transmitter antenna, processed within the control unit, and displayed on the graphic recorder or recorded on magnetic tape, or both. The reflections received were composite returns from a spherically expanding volume of energy centered on the antenna that usually appeared as a group of three bands on the graphic record. These bands are characteristic of the GPR system, and were caused by oscillations in the transmitted pulses (G.R. Olhoeft, U.S. Geological Survey, written commun., 1989).

The recorded data represents the total travel time for a GPR signal to pass from the antenna, through the subsurface to a reflector, and return to the antenna. A longer time between transmission and reception of a signal in a given homogeneous unit generally implied a greater distance to an interface (Wright and others, 1984). However, differing velocity structures and raypaths can complicate the time/distance relation.

\section{Ground-Penetrating Radar Surveys}

From May 1986 through October 1987, 120 GPR traverses ranging in length from 600 to $42,000 \mathrm{ft}$ and totalling approximately $125 \mathrm{mi}$, were run in the study area. The work was accomplished in 41 eight-hour working days, for an average coverage of about 3 linear miles of GPR survey traverse per day. Before each survey, the length of the survey line was measured using a bicycle-wheel measuring device and stations were marked on the ground with paint every $200 \mathrm{ft}$. The control unit and recorders were transported in a van and the GPR antenna was towed $25 \mathrm{ft}$ behind the van. As the antenna passed a station mark, a marking pulse on both the graphic and tape recorders was triggered manually, and the operator labelled the marks on the graphic record. After a survey was completed, elevations of the station marks were obtained by leveling, and the GPR record was converted to water-table altitudes by subtracting the 
depth to the water table interface from the surveyed station elevation.

Three persons were needed to efficiently complete a GPR survey. During the survey, one person drove the vehicle, the second operated the electronics and took notes, and the third manually steered the antenna and triggered the marking pulses.

The reflected signals received by the antenna were displayed on a cathode-ray-tube (CRT) screen on the control unit and on the printout from the graphic recorder. The operator monitored the return signals and later processed the raw signal data that had been recorded on magnetic tape.

An example of the radar signal on the CRT screen and corresponding display on the graphic recorder is shown in figure 6. The graphic record is a composition of a parallel series of amplitude versus time displays. The darkness of the graphic record is proportional to the amplitude of the reflected signal. Vertical position corresponds to the two-way travel time of the signal from antenna to interface and return.

Transporting the electronics in a van provided protection, controlled temperature, and a power source for the electronics, but limited the location of surveys to well-defined paths and roads with firm surfaces. Although not attempted in this study, the electronics can be transported in a trailer or on a sled towed behind a small all-terrain vehicle for surveys in swampy areas or on narrow paths.

The antenna was generally steered manually to protect the antenna and to locate station marks accurately. This limited the rate of data collection to a fast walking pace, or about 2 to $3 \mathrm{mi} / \mathrm{h}$. When the surveys were made in open, fairly level areas, the antenna could be towed without manual guidance, and the rate of data collection was 3 to $5 \mathrm{mi} / \mathrm{h}$.

The antenna was generally towed $25 \mathrm{ft}$ behind the vehicle because it allowed for easy control and maneu-

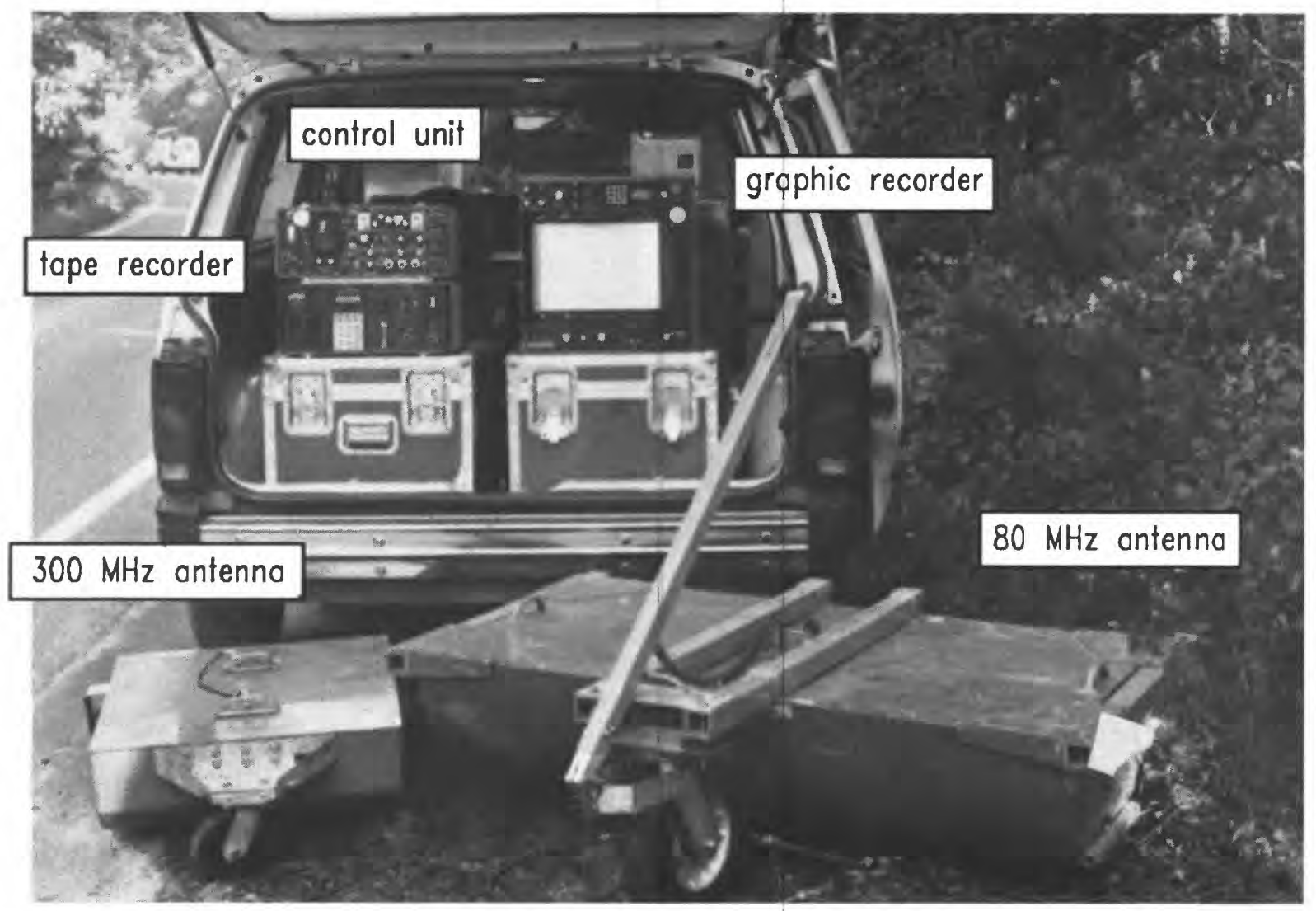

Figure 5.--Ground-penetrating radar equipment. 


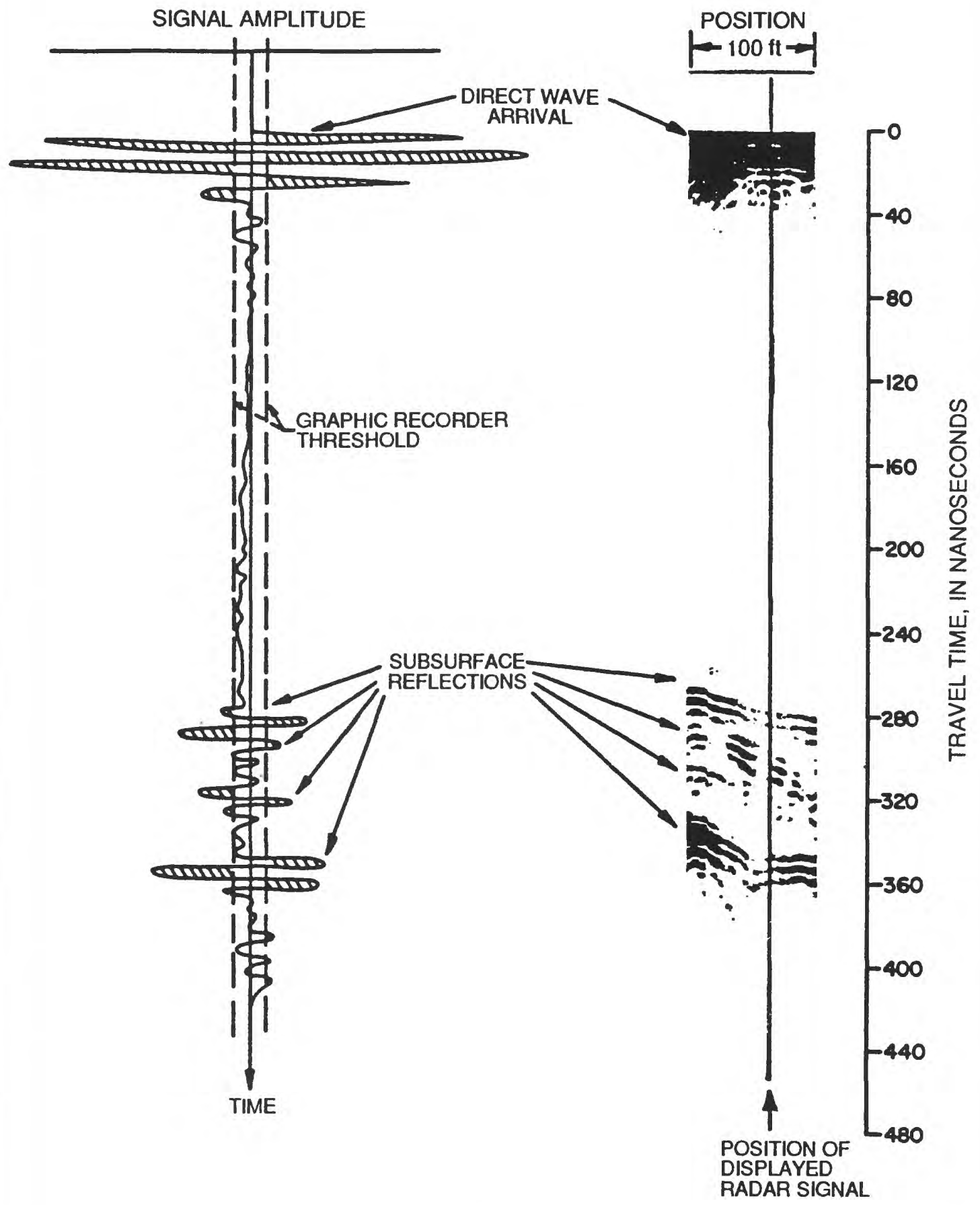

Figure 6.--Appearance of a radar signal on a cathode ray tube screen and on a graphic recorder. (Modified from Davis and others, 1984, fig. 3.)

(Reprinted by courtesy of National Water Well Association.) 
verability of the antenna, easy communication between the operator and the person steering the antenna, and minimal reflections on the GPR record from the towing vehicle. When the antenna was towed 50 - or $100-\mathrm{ft}$ from the vehicle, no reflections from the towing vehicle were observed on the GPR record, however, noise from the electronics and vehicle made communication difficult and the tow cable frequently hung up on brush and trees along the edge of the roads when sharp turns were made.

When the $80-\mathrm{MHz}$ antenna was towed $2 \mathrm{ft}$ behind the vehicle, a reflection in the form of a continuous dark band was present across the middle of the graphic record. The $80-\mathrm{MHz}$ antenna is not shielded and so some signals were transmitted in all directions about the antenna. Signals transmitted above ground from the antenna were reflected back to the antenna from the towing vehicle. Towing the $80-\mathrm{MHz}$ antenna at least $25 \mathrm{ft}$ from the vehicle minimized these reflections. When surveys were made parallel to nearby overhead power lines, the type of reflection discussed above also was present on the record. Therefore, surveys near power lines were avoided. The $300-\mathrm{MHz}$ antenna used in this study was shielded on the top and sides, so all transmitted signals were directed into the subsurface and no reflections from the towing vehicle appeared on the graphic record regardless of the distance between the antenna and the towing vehicle.

Upon completion of the survey, two persons performed the leveling along the survey line while the operator completed the notes, performed any necessary processing of the data, and prepared for the next survey. With a crew of three, and leveling performed on all survey lines, 4 to $6 \mathrm{mi}$ of GPR survey could be completed during an 8-hr work day.

Most field time was spent in determining the altitude of the land surface at the GPR stations. For example, a 5,000-foot survey over narrow, winding roads, with stationing every $200 \mathrm{ft}$, typically required 20 minutes to collect GPR data and 45 to 60 minutes for leveling. Land-surface altitudes were determined to 0.1 -ft precision, and were accurate to within about $0.2 \mathrm{ft}$ per mile of traverse distance. Because of the time involved, closed-loop leveling was not performed, but a self-leveling level was used and checked weekly for accuracy. Accurate leveling is as critical in mapping water-table altitudes using GPR as it is when using water levels for observation wells.

\section{INTERPRETATION OF THE GROUND- PENETRATING RADAR RECORD}

\author{
Depth of Penetration of the Ground- \\ Penetrating Radar Signal
}

The principal limitation of the use of GPR is the depth to which the radar signal can penetrate the ground. In this study, the GPR signal penetrated depths that ranged from less than $3 \mathrm{ft}$ in areas of lake deposits near Cape Cod Bay to over $95 \mathrm{ft}$ in the higher elevations of the outwash plain near the center of the study area. The GPR records showed that least penetration occurred in the lake-deposit areas, variable penetration occurred in the areas of ice-contact deposits, and greatest penetration occurred in the outwash plain. According to Oldale's (1969) description of the area, fine-grained materials occur near the surface in areas of lake deposits, materials of various grain sizes occur in the areas of ice-contact deposits, and coarse-grained materials occur near the surface in the areas of the outwash plain. Clays compose a large portion of the fine-grained material found in the surficial materials in the study area. This may explain some of the limitations to signal penetration in the lake-deposit and ice-contact deposit areas.

According to Olhoeft (1984), the depth of penetration is controlled by electrical conductivity, water content, scale of electrical inhomogeneity, and clay content in the soil. These controlling factors change the electromagnetic energy (GPR signal) into forms that cannot be received by the GPR system. Water saturated sediment with high electrical conductivity transforms the electromagnetic energy into thermal energy; the rotation of the dipolar water molecule in the electromagnetic field turns electromagnetic energy into mechanical energy, and, in a viscous medium, then into thermal energy; changes in electrical properties in a material (inhomogeneity) on the same geometric scale as the wavelength of electromagnetic propagation scatters the electromagnetic energy into random directions rather than back toward the antenna; diffusion-limited chemical processes around colloidal-sized particles (such as mineralogic clay) then turn electromagnetic energy into chemical energy (Olhoeft, 1984, 1987).

Predicting the success of GPR methods would require prior geologic knowledge of the area of interest to determine whether the subsurface conditions are favorable for the use of GPR. This investigation could 
be as simple as a review of existing information to determine the local lithology. A more time-consuming, but probably more informative preliminary investigation would involve performing a direct current (DC) or very low frequency (VLF) resistivity survey to determine the effectiveness of the GPR method.

\section{Identification of the Water-Table Reflector}

The top of the saturated zone was usually the most distinct continuous reflector below the land-surface reflector on the GPR record. The strength or distinctness of the saturated zone reflector depends on the contrast between the electrical properties of the unsaturated and saturated zone, the distance over which the contrast occurs, and sharpness of that boundary compared to the wavelength of the radar signal transmitted into the ground. In coarse-grained sands, the capillary fringe is usually thin, especially during dry periods, which is a result of gravity drainage of the larger pore spaces. The water-table reflector is usually very distinct in these deposits and the position of the water table on the graphic record is relatively easy to locate. In fine-grained materials, the capillary fringe may be somewhat variable in thickness because of the variable amounts of small, interconnected pore spaces causing the exact position of the saturated zone reflector on the graphic record to be indistinct and difficult to locate. For this study, the saturated zone reflector was taken to represent the position of the water table (the interface between unsaturated and saturated soils where hydrostatic pressure equals atmospheric pressure).

Of the 120 GPR survey lines made during the study, very distinct water-table reflectors were present in 70 . All of the lithologic logs of 31 wells located along some of these survey lines confirmed the presence of coarse and medium sand at or near the depth of the water table at these wells. Of the remaining 50 surveys, water-table reflections were found in all but 5 of the surveys. All five surveys were made in the lake-deposit areas where a large capillary fringe did not provide a distinct water-table reflection. The presence of fine sands, silts, and clays, as determined by lithologic logs of wells along the survey lines, causes a reduction of the distinctness of the water-table reflector on the GPR record.

Shih and others (1986) determined that the electromagnetic contrast between dry and wet layers de- creases with increasing amounts of fine-grained materials. This generalized trend was assumed to be partially responsible for the distinct water-table reflections present in coarse-grained materials. However, in this study and the study by Shih and others (1986), not all coarse-grained materials yielded distinct water-table reflectors. As the number of soil layers increased, the water-table reflection was commonly superposed upon other reflections, making water-table identification difficult or impossible. Also, the characteristic triple band on the GPR record (figs. 7 and 8) limited the ability of the GPR to discriminate between closely spaced interfaces, causing the water-table profile to blend in with and become masked by other interfaces. The low frequency signals provided for deep penetration, but the long wavelength of the signal prevented discrimination of thin layers.

Although the $300-\mathrm{MHz}$ antenna provided greater resolution of interfaces and structural detail than did the $80-\mathrm{MHz}$ antenna, the $80-\mathrm{MHz}$ antenna generally produced a better graphic image of the water table when depth to water from the land surface exceeded $10 \mathrm{ft}$. The long pulse width characteristic of the $80-\mathrm{MHz}$ antenna caused superpositioning of closely spaced interfaces, which obscured thin layers on the radar record. Where the water table was shallow, the short pulse width of the $300-\mathrm{MHz}$ antenna was used to obtain resolution between the closely spaced interfaces.

In addition to the water table, other subsurface features, such as layering and bedding of stratigraphic units, discontinuous clay layers, boulders, and buried pipelines, were observed on the GPR records. Some excellent examples of these features are given in Morey (1974), Ulriksen (1982), Wright and others (1984), and Collins and Doolittle (1987).

\section{Signal-Propagation Velocities in Unsaturated Materials}

The depth to the water table from land surface can be calculated if the propagation velocity of the GPR signal through the unsaturated earth and the travel time are known. Velocities of GPR signals in unsaturated materials were determined along the survey lines using water levels in observation wells and ponds. The average velocity of the signal in the unsaturated zone $\left(V_{m}\right)$ was calculated from the following equation: 


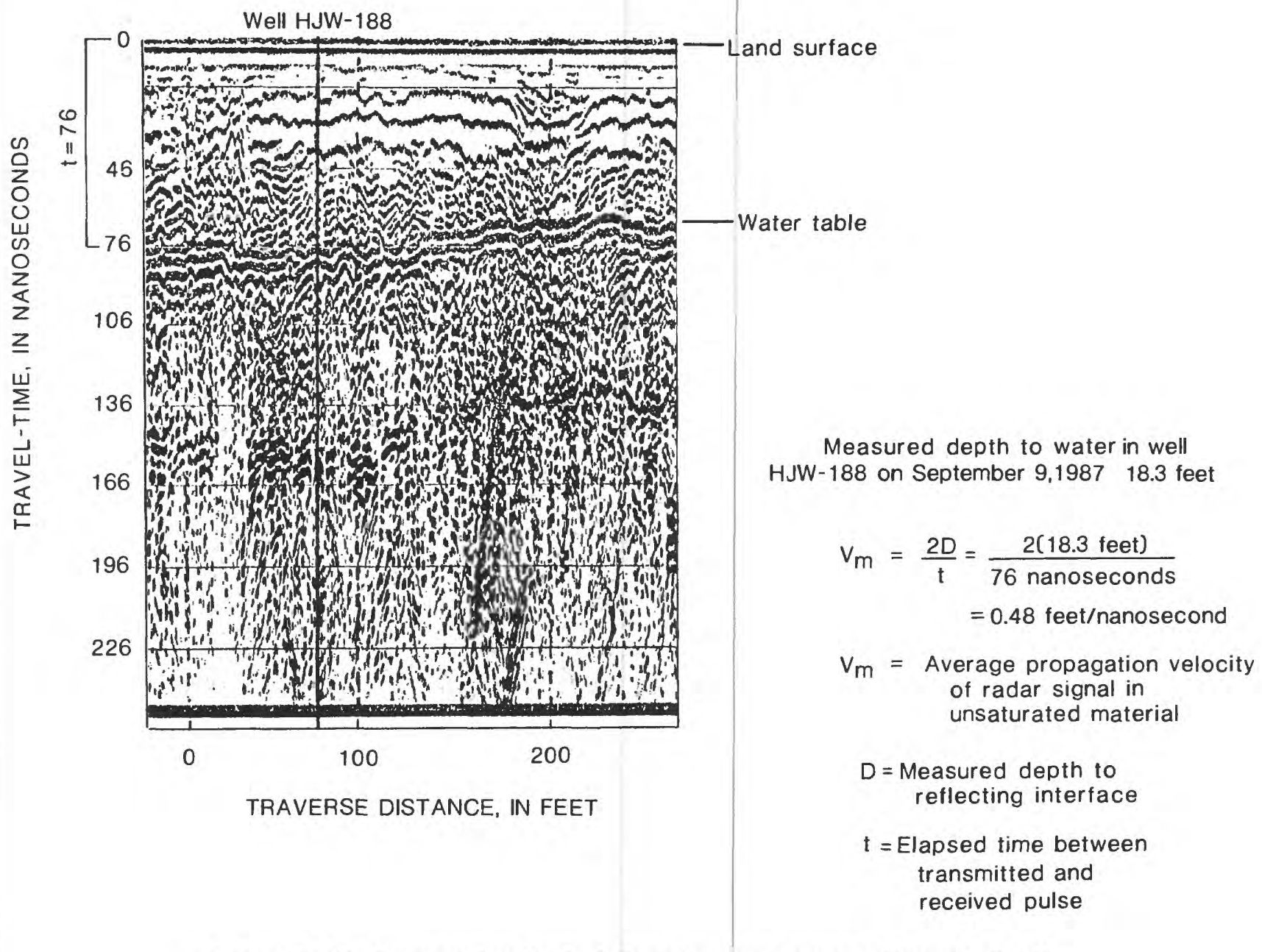

Figure 7.--Radar record and calculation of average propagation velocity of radar signal in the unsaturated zone.

$$
\mathrm{V}_{\mathrm{m}}=2 \frac{\Delta}{\mathrm{t}}
$$

where $\Delta$ is the measured depth from the land surface to the water table at an observation well or pond, in $\mathrm{ft}$; and

$t$ is the elapsed time between

transmitted and received pulse, in nanoseconds

(ns, $1 \mathrm{~ns}=1 \times 10^{-9}$ second).

The depth to the water table from the land surface was measured in the observation wells using a steel tape and at the edge of ponds by leveling. The two-way travel time of the signal passing through the unsaturated zone was measured on the graphic record from the top of the reflective bands representing the land surface to the top of the reflective bands representing the water table. An example of the radar record and calculations is shown in figure 7 .

An alternative method can be used to determine the propagation velocity of the GPR signal in the unsaturated zone when wells and ponds are not available. This method requires placement of a stationary transmitting antenna at the land surface over a reflective horizontal subsurface interface, such as the water table, and moving a receiving antenna of the same frequency in a straight line along the land surface away from the transmitting antenna at a uniform rate. As the time/distance relation of the radar signal from the transmitting antenna to receiving antenna 


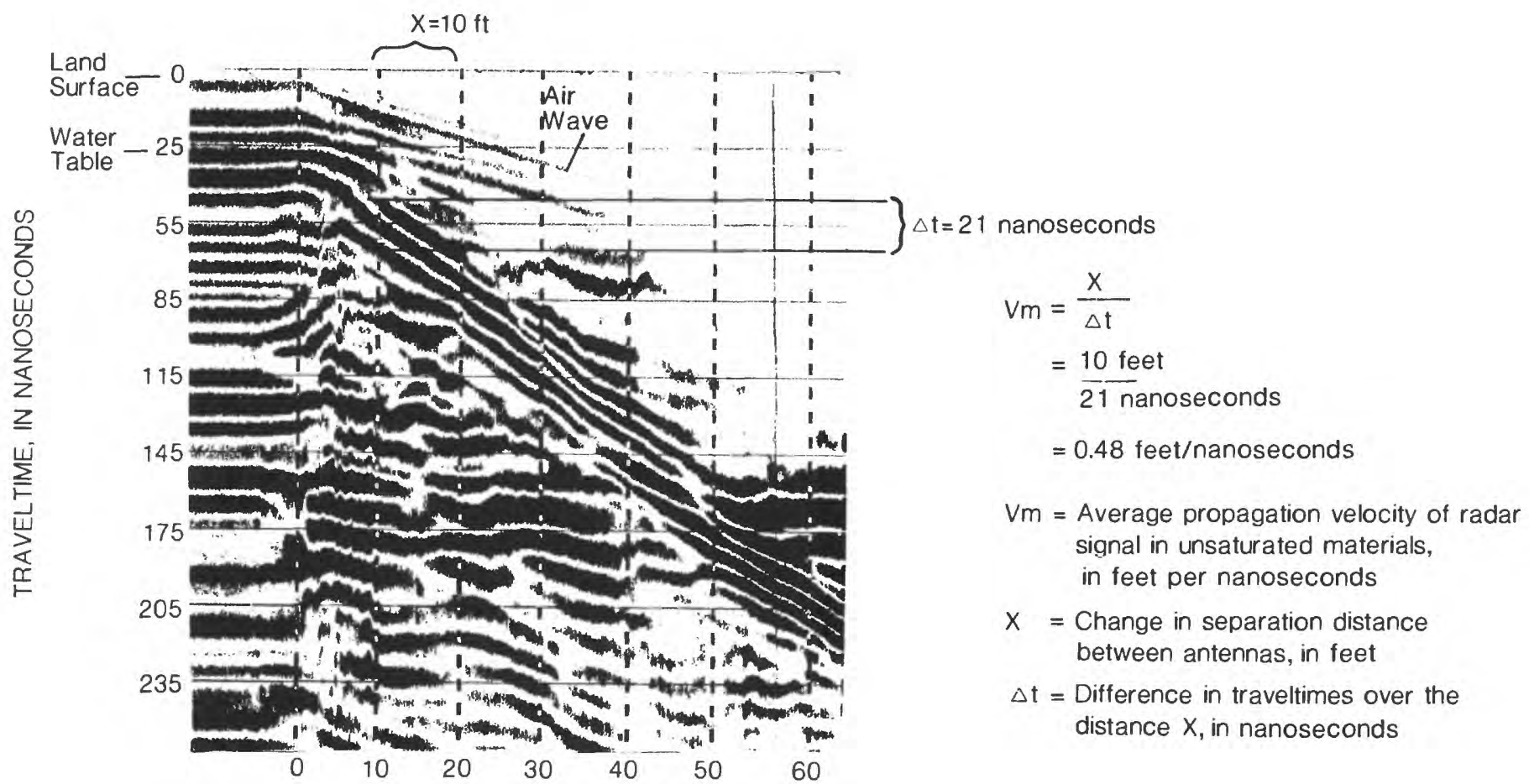

ANTENNA SEPARATION DISTANCE, IN FEET

Figure 8.--Radar record and calculation of average propagation of radar signal velocity in the unsaturated zone using a stationary and a moving antenna.

becomes linear, the direct signal travels below the earth's surface at a speed $V_{m}$ (Dobrin, 1976), so that-

$$
\mathrm{V}_{\mathrm{m}}=\frac{\mathrm{X}}{\Delta \mathrm{t}}
$$

where $\frac{X}{\Delta t}$ is the inverse of the slope of the reflecting line of the water table on a plot of $t$ versus $X$,

$\mathrm{X}$ is the difference in separation

distance between antennas, in $\mathrm{ft}$; and

$\Delta t$ is the change in travel times, in nanoseconds, over the distance $\mathrm{X}$.

The difference in travel times of the GPR signal as the receiving antenna is moved away allows for computation of the GPR signal velocity in the material above the water table. In the example shown in figure 8, the GPR signal velocity in the unsaturated zone computed by this method is $0.48 \mathrm{ft} / \mathrm{ns}$.

This moving antenna method of determining signal velocity can be useful to determine the velocity in areas where the thickness of the unsaturated zone is not known because of absence of reference elevations for calibration. In this study, results obtained at two sites using the moving-antenna method agreed with velocities calculated using known thickness of the unsaturated zone and travel times at observation wells. The major drawbacks of this method are the need for two antennas of the same frequency, and the time required (approximately one-half hour) to set up the survey and perform the procedure.

Propagation velocities of the GPR signal in unsaturated materials were determined near 21 ponds and 64 wells. The velocities at all sites were determined using equation 1, and ranged from 0.33 to $0.51 \mathrm{ft} / \mathrm{ns}$, with a mean of $0.44 \mathrm{ft} / \mathrm{ns}$ and median of $0.45 \mathrm{ft} / \mathrm{ns}$. Depth to water at these sites ranged from 2 to $77 \mathrm{ft}$ below land surface. Eighty of the 85 sites were located in glacial outwash, where the average velocity was $0.45 \mathrm{ft} / \mathrm{ns}$. Velocities determined for two sites located in lake deposits were 0.38 and $0.47 \mathrm{ft} / \mathrm{ns}$ and for three sites located in ice-contact deposits were $0.43,0.44$, and $0.48 \mathrm{ft} / \mathrm{ns}$. 


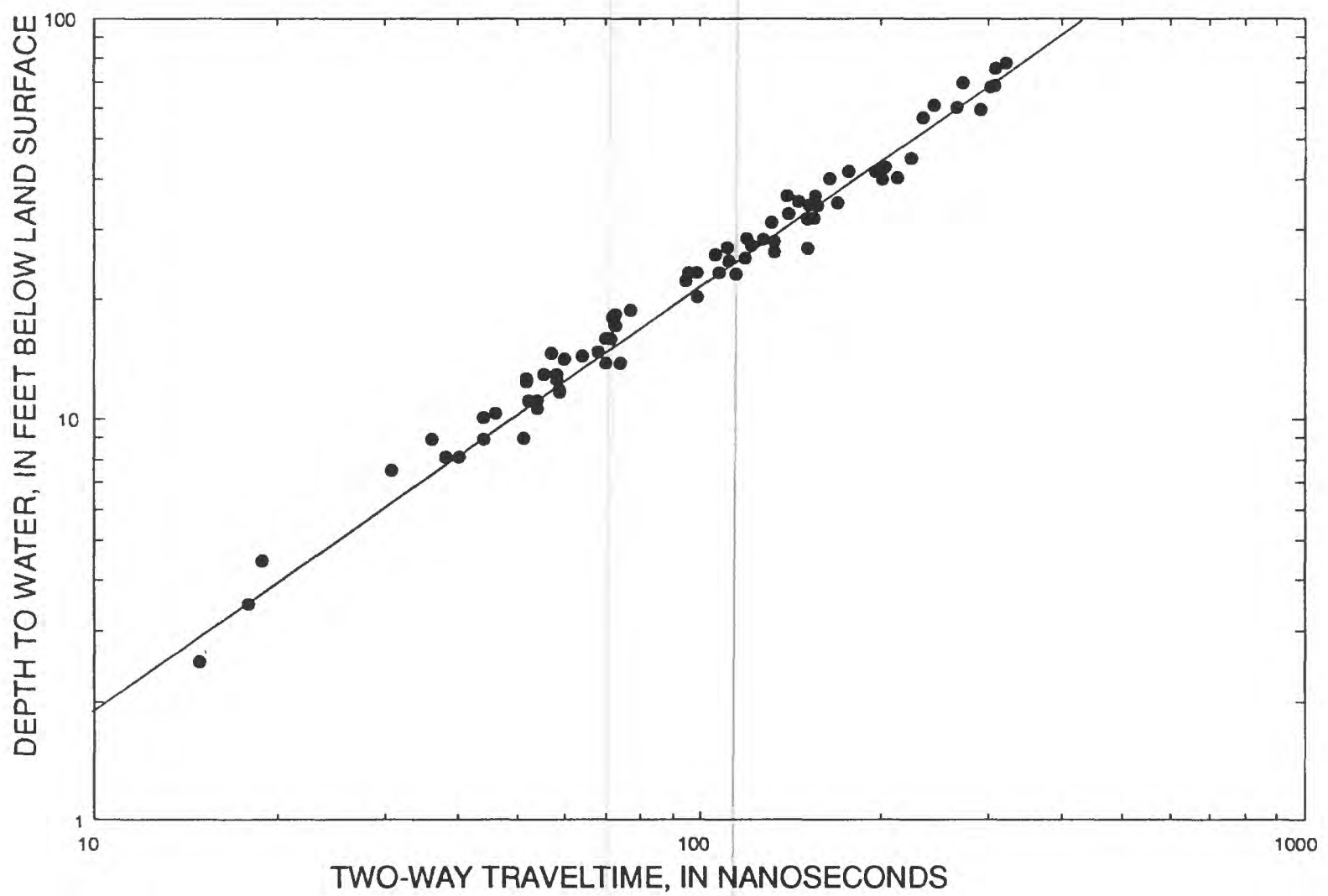

Figure 9.--Relation between depth to water and two-way travel time.

Signal velocities in the unsaturated material did not appear to be significantly affected by the thickness of the unsaturated zone or the season of the year, but did appear to be slightly affected by the composition of the road material over which the surveys were made. Regression of thickness of the unsaturated zone against GPR signal velocities in the unsaturated zone at the sites showed no apparent correlation (coefficient of determination $\left(R^{2}\right)=0.063$ ), and therefore, velocities do not appear to be related to thickness of the unsaturated zone.

Mean GPR signal velocities obtained from 38 observations in the late spring (June 1986 and May 1987) and 46 observations in the early fall (September to October 1986 and 1987) were 0.44 and $0.45 \mathrm{ft} / \mathrm{ns}$, respectively, and were not significantly different $(p=0.13)$ at a 95-percent confidence level.

Results of surveys made at 65 sites on dirt roads and 20 sites on paved roads showed mean GPR signal velocities in the unsaturated zone were slightly higher for dirt roads $(0.45 \mathrm{ft} / \mathrm{ns})$ than paved roads $(0.43 \mathrm{ft} / \mathrm{ns})$. For example, using equation 1 and a travel time of 100 $\mathrm{ns}$, the difference between the two velocities, in terms of depth, is about 5 percent ( $22.5 \mathrm{ft}$ versus $21.5 \mathrm{ft}$ ). This comparison does not consider the effects of compaction or composition of sub-base construction materials.

\section{Determination of Water-Table Altitudes by Ground-Penetrating Radar}

One GPR signal velocity was used throughout the study area to determine depths to the water table from land surface. This velocity $(0.45 \mathrm{ft} / \mathrm{ns})$ was the average velocity calculated at 85 ponds and observation wells where the depth to the water table below land surface was known. The average velocity is based on the correlation between the measured depths to water from land surface at the 85 pond and observation wells and the two-way travel times of the GPR signal between land surface and the water-table reflector identified on the GPR record at the 85 sites. 
A regression of these two variables (fig. 9) shows that they were strongly correlated at the 85 sites $\left(R^{2}=\right.$ 0.984 , percent standard error of estimate $=8.8$ ). Depth to water at the calibration sites ranged from 2.5 to $77 \mathrm{ft}$ below land surface, with an average depth of $27 \mathrm{ft}$.

The two-way travel times for the 85 calibration sites and the average velocity of $0.45 \mathrm{ft} / \mathrm{ns}$ were applied to equation 1 to obtain depths to the water table from land surface. The depths predicted using the 0.45 $\mathrm{ft} / \mathrm{ns}$ velocity were compared with the actual depths at the 85 sites. The mean of the differences at all 85 sites was 7.2 percent $(1.8 \mathrm{ft}$ ), with a standard deviation of 6.4 percent $(1.8 \mathrm{ft})$. The difference between the predicted and actual values of depth to water below land surface showed a constant variance with increasing depth to water from the land surface. This analysis suggests that in parts of the study area where water levels are unknown, application of a velocity of 0.45 $\mathrm{ft} / \mathrm{n}$ s is an appropriate value to be used when estimating the depth to water.

The results of the accuracy of GPR in determining depth to water from the land surface are similar to those reported for studies conducted in small areas in Florida. Shih and others (1986), compared depth to water from the land surface derived by GPR with water level in observation wells, in an area where the average depth to water was $6.5 \mathrm{ft}$. They reported an average of 3 percent and a standard deviation of 1.5 percent at 15 calibration sites in a study area of approximately $630,000 \mathrm{ft}^{2}$. Using GPR to determine depths from the land surface to two soil horizons at about 1.1 and $3.4 \mathrm{ft}$ below ground surface, Collins and Doolittle (1987) reported an average error of about 7 percent at eight calibration sites in a $990 \mathrm{ft}^{2}$ study area.

The accuracy of GPR for determining water-table altitudes is controlled by a number of factors. Individually or combined, these factors can cause significant errors in the calculated water-table altitudes along the GPR survey lines. The main factors are the degree of homogeneity of relative dielectric constant in the unsaturated zone along a GPR survey line, which is largely dependent on moisture content of the soils, and accurate measurement of the two-way travel time of the GPR signal in the unsaturated zone.

The velocity of the GPR signal is extremely sensitive to changes in relative dielectric constant. Changes in moisture content, resulting from uneven recharge, variations in the type and density of material in the unsaturated zone, or both, change the value of the relative dielectric constant in the unsaturated zone significantly. For example, Jesch (1978), in laboratory tests using a $300-\mathrm{MHz}$ signal, found that sand samples with an average density of $101 \mathrm{lb} / \mathrm{ft}^{3}$ and moisture contents of $0,1,4$, and 8 percent had average relative dielectric constants of $2.7,3.2,4.2$, and 7.0, respectively. The relative dielectric constant is related to the signal propagation velocity by the equation--

$$
\mathrm{Er}=\left(\frac{\mathrm{c}}{\mathrm{V}_{\mathrm{m}}}\right)^{2}
$$

where $\mathrm{Er}$ is the relative dielectric constant,

c is the propagation velocity

in free space, which is equal to one foot per nanosecond; and

$V_{m}$ is the signal propagation velocity, in feet per nanosecond.

The GPR signal velocity in sand with a dielectric constant of 2.7 was $0.61 \mathrm{ft} / \mathrm{ns}$, whereas the GPR signal velocity in sand with a dielectric constant of 3.2 was $0.56 \mathrm{ft} / \mathrm{ns}$. Further, using equation 1 and a travel time of $100 \mathrm{~ns}$, the difference between the two velocities, in terms of depth, is $2.5 \mathrm{ft}$ ( $30.5 \mathrm{ft}$ compared to $28 \mathrm{ft}$ ). Therefore, a variation in relative dielectric constant from 2.7 to 3.2 resulting from a difference in moisture content of one percent, will cause a variation in depth calculation of 8 percent.

Laboratory studies made by Bowders and others (1983), showed that the time for a GPR signal to travel from the surface to the bottom of a sand-filled box increased as the percent saturation with fresh water was increased. As moisture content increased, the signal velocity decreased, thereby increasing the apparent depth to the bottom of the box.

Accurate calculation of water-table altitudes depends not only on proper calibration of the propagation velocity of the GPR signal, but also accurate measurement of the two-way travel time between the land surface and the water table on the graphic record. The top of the land surface on graphic records is not always a distinct flat line and the top of the water-table band is commonly less distinct. Incorrect identification of the top of these bands on the graphic record can lead to error in calculation of the depth to the water table, particularly for shallow depths, because small differences in travel time can result in large differences in calculated depths. For example, using equation 1, a velocity of $0.45 \mathrm{ft} / \mathrm{ns}$, and travel times of $36 \mathrm{~ns}$ and 40 $\mathrm{ns}$, calculated depths are 8.1 and $9.0 \mathrm{ft}$, respectively. 
Although GPR records provide continuous watertable profiles, water-table altitudes were calculated at discrete stations every $200 \mathrm{ft}$ along survey lines. The two-way travel time from the land surface to the top of the water table was measured on the graphic record at each of the stations along the line. Depth to water from the land surface was then calculated by substituting the measured travel time and the average mean GPR signal velocity of all calibration sites $(0.45$ $\mathrm{ft} / \mathrm{ns}$ ) in equation 1 . On many GPR profiles, the top of the water table was difficult to identify, and was approximated by interpolation between identifiable sections. After the depth was calculated and subtracted from the land-surface altitude at each station, the water-table altitudes of the entire line were plotted on a vertical profile, and a smoothed curve was drawn through the data points (fig. 10).

If the actual water table is fairly flat, as is shown in the record interpretation in figure 10 , the water-table profile on the radar record appears as an approximate, although subdued, mirror image of the topographic expression. From station $0 \mathrm{ft}$ to station $200 \mathrm{ft}$ in figure 10 , the water table slopes upward toward the land surface on the radar record, whereas the record interpretation shows that the topography is sloping downward along this distance.

The record interpretation shown in figure 10 is a gross simplification of the actual topographic and watertable expression along the radar profile. Because water-table altitudes were calculated at $200 \mathrm{ft}$ intervals, considerable detail of the water-table structure shown in the radar record is lost during the interpretation. The $200 \mathrm{ft}$ calculation interval was selected to facilitate rapid collection of land-surface-elevation data over the large study area. Water tables are rarely flat or smoothly variable over large distances; thus, for detailed analyses, topographic corrections need to be made every 20 to $50 \mathrm{ft}$ (G.R. Olhoeft, U.S. Geological Survey, written commun., 1989).

\section{Comparison of Ground Penetrating Radar and Seismic Refraction}

Water-table profiles determined using GPR and those determined using seismic-refraction methods were compared with water levels in observation wells at three sites in Brewster (see plate 1 for locations) where the depth to water from the land surface averaged $4 \mathrm{ft}$ (section $\mathrm{B}-\mathrm{B}^{\prime}$ ), $16 \mathrm{ft}$ (section $\mathrm{C}-\mathrm{C}^{\prime}$ ), and $68 \mathrm{ft}$ (section D-D') (fig. 11).
Seismic-refraction field data were collected using a 12-channel seismograph with a small explosive sound source. Geophones were spaced every $20 \mathrm{ft}$ at sections B-B' and C-C', where the water table was shallow, and every $50 \mathrm{ft}$ at section D-D', where the water table was deep. Shot points were placed every $120 \mathrm{ft}$ along the lines with 20 -foot geophone spacing, and every $300 \mathrm{ft}$ along the line with 50 -foot geophone spacing. Depth to the water table from the land surface was calculated under each geophone using a seismic-refraction inverse-modeling program (Scott and others, 1972; Scott, 1977), which is based on the time-delay method described by Pakiser and Black (1957).

The mean radar signal velocity for the 85 sites in the study area $(0.45 \mathrm{ft} / \mathrm{ns})$ was used to interpret the GPR water-table profiles. The GPR record was interpreted at $100-\mathrm{ft}$ intervals along section B-B', 20 -ft intervals along section $\mathrm{C}-\mathrm{C}$, and 50 -ft intervals along section D-D'. Water-table altitudes calculated at each of these points from GPR and seismic-refraction data were plotted on the profiles shown in figure 11. The variation of the water-table profile determined by the two geophysical methods was attributed to the variability of subsurface conditions along the profile.

At these three sites, the calculated water-table altitude from the two geophysical methods and the altitude measured at the observation wells were compared (table 2). The results indicate a good agreement between the geophysically-determined watertable altitudes and those altitudes measured at selected observation wells.

In this study, GPR methods were more efficient than seismic-refraction methods for mapping the water table in coarse-grained materials. The GPR record provides much higher resolution of the subsurface than the seismic-refraction records. The GPR technique provided greater areal coverage in a given amount of time than did the seismic-refraction technique. The setup-and-breakdown-of and need to overlap seismic-refraction profile lines was very time consuming. However, the seismic-refraction method can penetrate deeper than can GPR, particularly in fine-textured soils. In general, accurate results from both GPR and seismic-refraction techniques are based on their proper application, some knowledge of the site's geology, and the experience of the interpreter. 

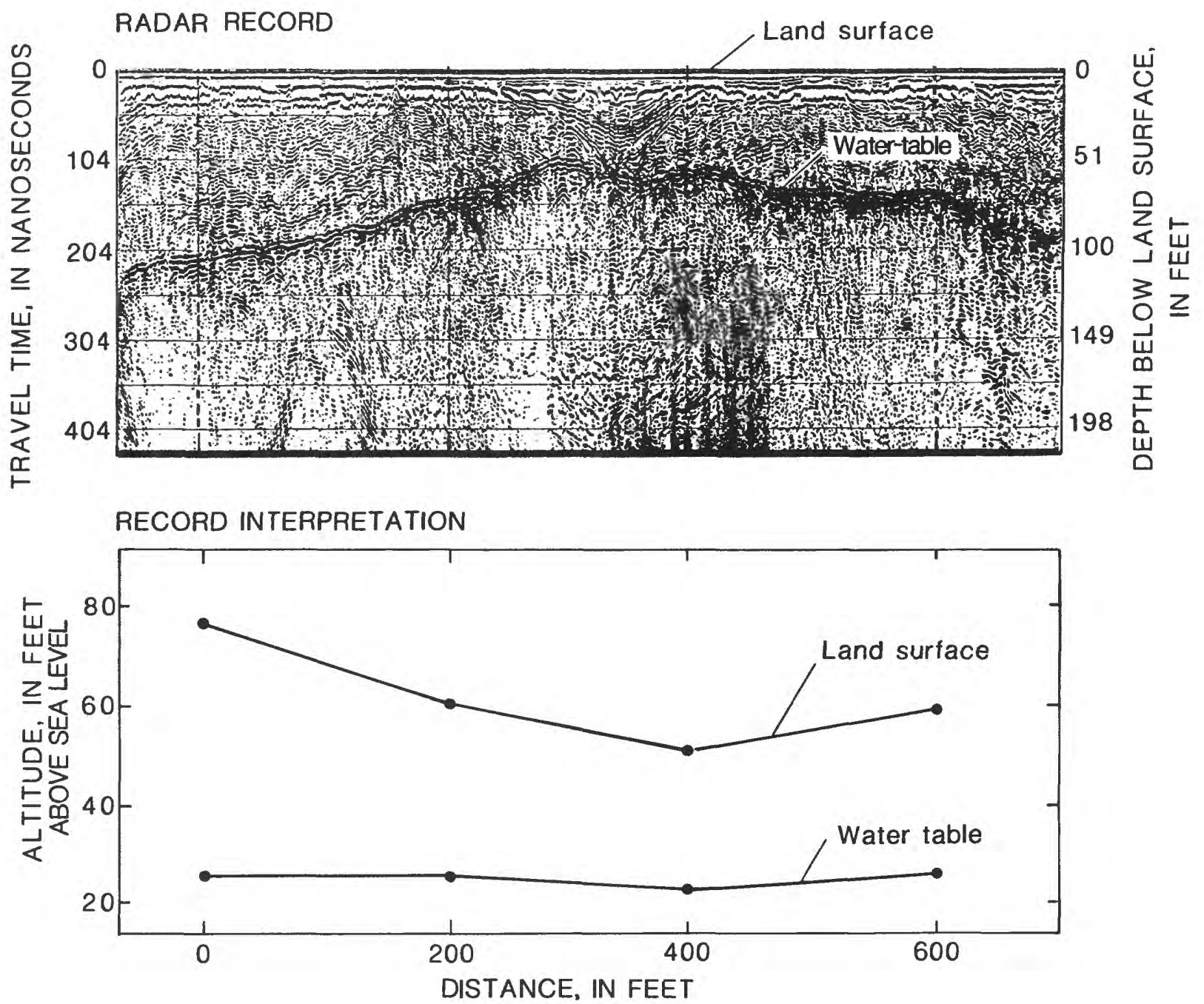

\begin{tabular}{|c|c|c|c|c|}
\hline \multicolumn{5}{|c|}{ Use equation 1, with Vm=0.45 foot per nonoseconds : } \\
\hline Station & 0 & 200 & 400 & 600 \\
\hline $\begin{array}{c}\text { Two-way } \\
\text { Travel time } \\
\text { (nanoseconds) }\end{array}$ & 210 & 150 & 110 & 140 \\
\hline $\begin{array}{c}\text { Calculated Depth } \\
\text { (feet) }\end{array}$ & 47 & 34 & 25 & 32 \\
\hline $\begin{array}{c}\text { Altitude of Land } \\
\text { Surfoce } \\
\text { (feet) }\end{array}$ & 75 & 62 & 51 & 63 \\
\hline $\begin{array}{c}\text { Altitude of } \\
\text { Water table } \\
\text { (feet) }\end{array}$ & 28 & 28 & 26 & 31 \\
\hline
\end{tabular}

Figure 10.--Sample ground-penetrating radar record showing a water-table profile and the record interpretation. 


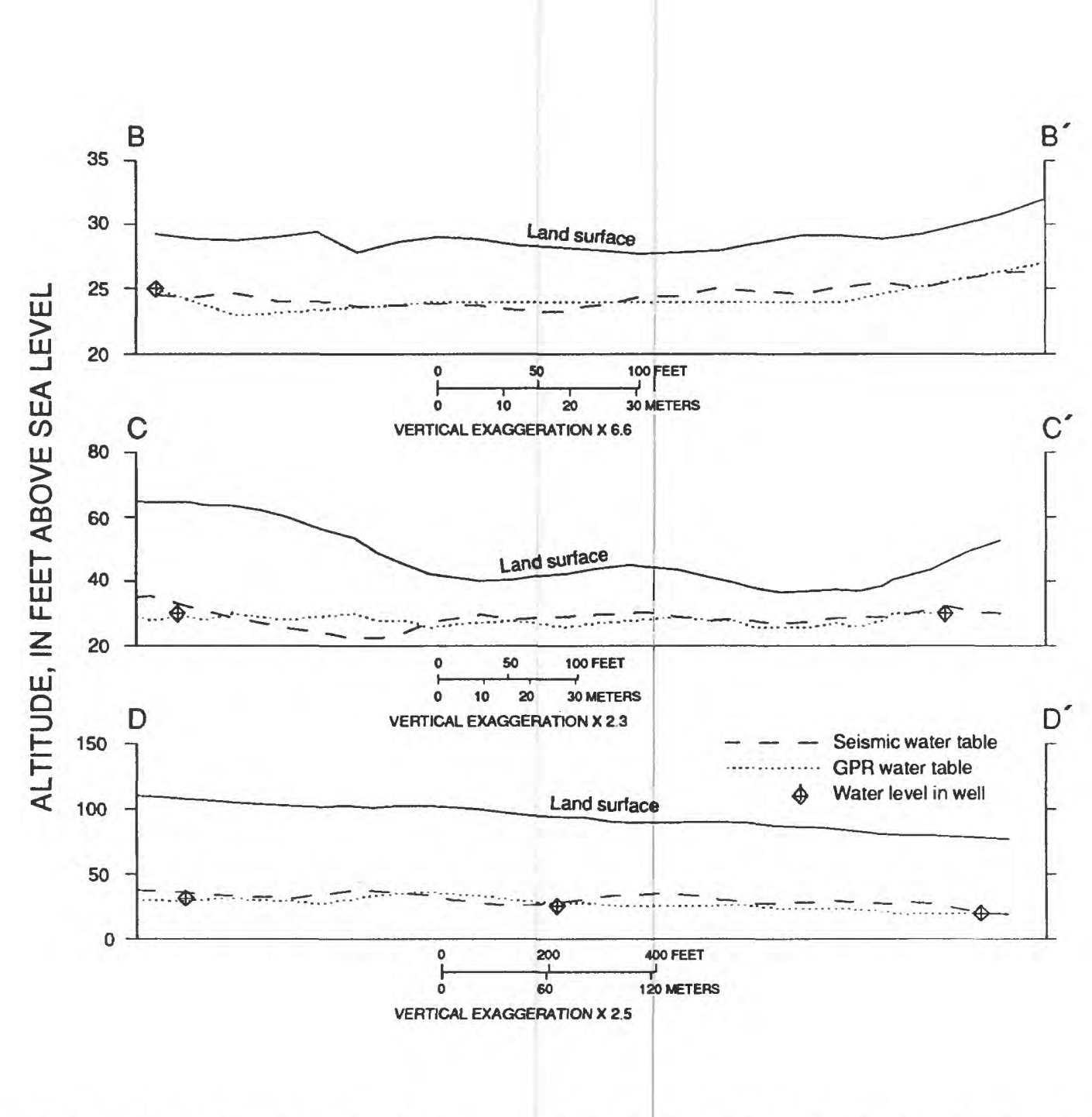

Figure 11.--Water-table profiles determined using ground-penetrating radar and seismic-refraction methods, and water levels in observation wells.

\section{WATER-TABLE MAPPING}

About 100 public and private observation wells in Brewster and Harwich on Cape Cod were located from information obtained from Federal and town officials and from local consulting firms. Water levels from these wells and from ponds in the area were used to map the water table and to calibrate GPR records. An additional 35 observation wells were drilled where no observation wells were present and where water-level information was lacking. Approximately 85 percent of the 135 wells were screened within $30 \mathrm{ft}$ of the water table. The altitudes of the observation wells were determined by leveling to within 0.05 foot; pond-surface altitudes and land-surface altitudes at GPR stations were determined by leveling to within 0.2 foot per mile of traverse length.
The altitude and configuration of the water table in the unconfined sand and gravel aquifer in the Towns of Brewster and Harwich, from September 21 to October 22,1987 , is shown on plate 1 . The water-table contours are based on water-level measurements at 75 observation wells, 36 ponds, Herring River, and on 180 water levels derived from 38 GPR surveys. Water levels were measured at 68 of the 75 wells from September 21 to October 1, 1987, and again from October 19-22, 1987. Between these two periods, water levels declined an average of $0.3 \mathrm{ft}$. The average of the two measurements at each well was used as the water-table altitude at that well. Water levels at the 36 ponds, Herring River, the remaining 7 wells, and from the GPR surveys, were measured once between September 21 and October 22, 1987. The altitude of water levels in wells and ponds are accurate to within 1 foot and from the GPR surveys are accurate to within about $2 \mathrm{ft}$ with respect to sea level. 
Table 2.--Measured water-table altitudes, and water-table altitude calulated by ground-penetrating radar and seismic refraction at selected observation wells, October 21-24, 1986

$[\mathrm{ft}$, feet]

\begin{tabular}{ccccc}
\hline Section & $\begin{array}{c}\text { Well } \\
\text { number }\end{array}$ & $\begin{array}{c}\text { Altitude of water table, } \\
\text { measured } \\
(\mathrm{ft})\end{array}$ & $\begin{array}{c}\text { Altitude of water table, } \\
\text { GPR-calculated } \\
(\mathrm{ft})\end{array}$ & $\begin{array}{c}\text { Altitude of water table, } \\
\text { seismic refraction- } \\
\text { calculated } \\
\text { (ft) }\end{array}$ \\
\hline B-B' & BMW-78 & 24.7 & 25.0 & 24.6 \\
C-C' & BMW-84 & 30.1 & 29.0 & 32.1 \\
& BMW-89 & 29.9 & 30.0 & 30.9 \\
D-D' & & & & 35.7 \\
& BMW-66 & 29.4 & 29.0 & 27.4 \\
& BMW-67 & 26.4 & 27.0 & 20.9 \\
\hline
\end{tabular}

The altitude of the water table in Brewster and Harwich ranged from sea level along Cape Cod Bay and Nantucket Sound to more than $34 \mathrm{ft}$ at the tops of two water-table mounds located northwest of Long Pond and west of Upper Millpond, both in Brewster. Ground-water levels near the coast are affected by tides, which can cause daily ground-water level fluctuations of up to $2 \mathrm{ft}$ (LeBlanc and others, 1986). Ground-water levels at observation wells BMW 21 and BMW 22 were about $1 \mathrm{ft}$ higher than normal in September and October 1987 than the 25-yr average water level. Therefore, most of the water-table altitudes shown on the map are probably $1 \mathrm{ft}$ higher than long-term average water-table altitudes for September and October over most of the area.

Thirteen public-supply wells in Brewster and Harwich were pumped intermittently before and during the measurement period. Therefore, the water-table altitudes in the vicinity of the pumping wells from September 21 through October 22, 1987 were expected to be somewhat depressed. Average daily withdrawal from the three Brewster public-supply wells was 0.7 $\mathrm{Mgal} / \mathrm{d}$ and from the ten Harwich public-supply wells was $1.36 \mathrm{Mgal} / \mathrm{d}$ during the period.

Using the 111 known water levels from ponds and observation wells, a water-table map with a 5-ft contour interval could have been developed for the study area by interpolating between known altitudes. However, the addition of the GPR data allowed for refine- ment of the water-table contours to 2 -ft intervals and improved the precision of the contours by providing data between wells and ponds.

Water levels derived from GPR permitted detailed determination of some features of the water table that would not have been evident from the pond and observation well data alone. These features include the extent and configuration of water-table mounds, the variation of gradients away from the tops of these mounds, and the steep water-table gradient along the Herring River (pl. 1).

Interpretation of the GPR data permitted detailed delineation of the 34-ft contour of a water-table mound located west of Upper Millpond. Using the GPR data, this contour was extended into Brewster from near a well in Dennis.

The GPR surveys made in the vicinity of the watertable mounds north and south of Long Pond aided in construction of contours in those areas. For example, variations of the water-table gradient south and east of the mound located south of Long Pond were delineated, which would not have been possible using the water levels from ponds and wells alone.

On the basis of five GPR surveys, water levels in two wells, and one water level on Herring River, contours were constructed that show a steeply sloping watertable, indicating that Herring River receives ground- 
water discharge. As a result of this observation, on July 21, 1988, streamflow measurements of the Herring River were made at the outlet from Hinckley's Pond and $1 \mathrm{mi}$ downstream where U.S. Route 6 crosses the river. The flow increased in this 1 -mi reach from 5.14 to $6.22 \mathrm{ft}^{3} / \mathrm{s}$, indicating that, at U.S. Route 6, one-sixth of the flow of the Herring River was derived from ground-water discharge. Knowledge of the local hydrology might have led an investigator to this conclusion, but the steep water-table gradient near Herring River probably would not have been accurately anticipated without the GPR data or a series of streamflow measurements along the stream.

The contours below the 20 -ft interval along Cape Cod Bay were based on water levels from ponds and wells alone. A large capillary fringe in this area made the GPR method inaccurate.

A computer-generated contour map (fig. 12) was constructed using data collected during this study to depict thickness of the unsaturated zone (depth to the water table from land surface) in the study area. The map can be used to make preliminary estimates of depths to water from land surface for construction engineering and design and for septic-systems regulation.

\section{Determining Zones of Contribution to Pumped Wells}

The Massachusetts Department of Environmental Protection (DEP) requires delineation of that zone of an aquifer that contributes water to a well (Zone II) before approving the permit for a new municipal supply well. One of the necessary elements required to delineate such a zone is a water-table contour map. To determine the zone of contribution to a public supply well, analytical methods or ground-water flow models are used to calculate drawdown, which is then superposed on the initial water table to derive the new configuration of the water table. Drawdowns as small as $0.1 \mathrm{ft}$ are used in these calculations, and the accuracy of the resultant pumping water-table map is highly dependent on the accuracy of the initial watertable map. Flow analysis of the map of the water table during pumping is made to define the flow lines which represent no-flow boundaries to the well, thereby delineating the zone of the aquifer that contributes water to the well.

The GPR method would seem to be a useful tool to aid in the determination of initial water-table maps if the 7-percent accuracy shown in this investigation were acceptable. However, application of the GPR method to produce detailed water-table maps in a $4-\mathrm{mi}^{2}$ area around Brewster supply wells $1-3$ and in a $6-\mathrm{mi}^{2}$ area around Harwich supply wells 1-7 to determine zones of contribution to wells, proved unsuccessful. Most all of the 15 GPR surveys made in these areas provided water-table profiles that were easy to identify and interpret on the graphic record but, the interpreted water-table altitudes differed considerably from point to point along the profiles and were impossible to contour. Most likely these irregularities in watertable altitudes are caused by delayed drainage from fine grain lenses and layers near the water table and within the well's cones of depression that cause velocity changes in the partially saturated material. The surveys were made over a 3- to 4-day period, during which the supply wells were pumped intermittently and rain fell, which may have caused variations in the drawdowns and recharge about the wells. One feature that was indicated in all interpreted profiles, was the general trend of the water-table slope. The slopes appeared to be consistent with the regional watertable slope and the slopes shown by water levels in nearby observation wells.

No drawdown of the water table by any single well or group of wells was apparent in any of the GPR profiles. The accuracy of the GPR method (7 percent) in this study indicates the method may not be precise enough to delineate small drawdowns of the water table around pumping wells. For example, in the study area, where average depth to the water from land surface is $20 \mathrm{ft}$, and accuracy of the method is about 2 $\mathrm{ft}$, a drawdown of $1 \mathrm{ft}$ caused by a pumped well may not be detected.

\section{Determining Water-Table Configura- tion Near Waste-Disposal Areas}

Water-table maps derived from GPR surveys can be used to determine ground-water flow directions near waste-disposal areas. Four GPR surveys were made in a $1-\mathrm{mi}^{2}$ area surrounding the Harwich landfill on September 24 and 26, 1986, to determine the watertable gradients. The gradients indicate the direction of ground-water flow and possible direction of dissolved contaminant flow in the vicinity of a landfill. The GPR surveys showed distinct water-table reflections, which were used to construct a detailed watertable map of this area (fig. 13). Although the general direction of ground-water flow is from north to south, 

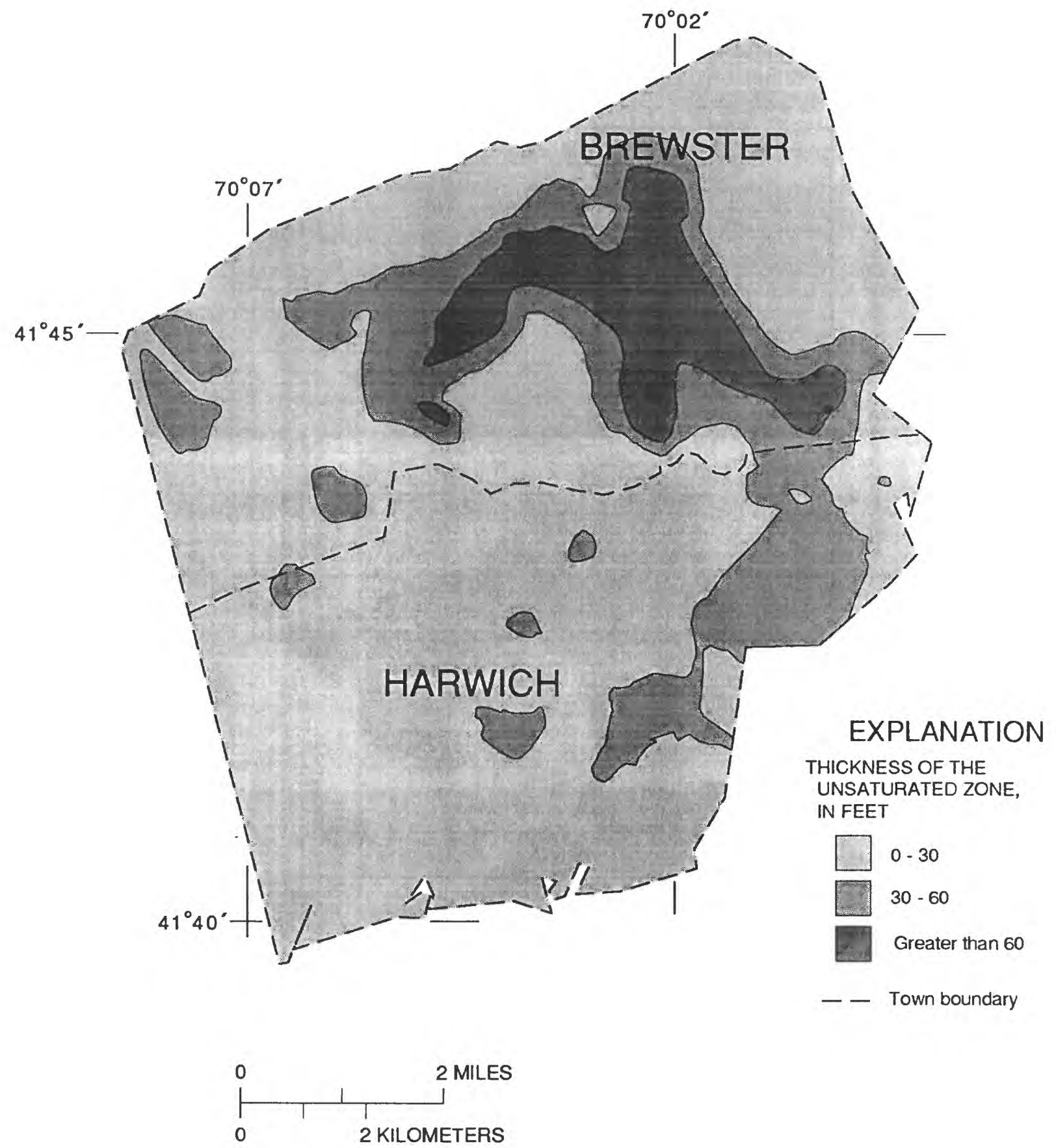

Figure 12.--Generalized thickness of the unsaturated zone, Harwich and Brewster, Massachusetts. 
in September of 1986, the GPR data suggested a water-table mound beneath the septage-disposal beds between the landfill and Flax Pond. In the fall of 1987 (pl. 1) no mound was detected, and flow beneath the landfill seemed to be from north to south into Flax Pond. The intermittent mound beneath the septagedisposal beds is interpreted as resulting from variable recharge from the dewatering of the septage.

The GPR data suggested the existence of a steep water-table gradient to the stream southwest of Flax Pond. The steep gradient results from the discharge of ground water to the stream.

\section{SUMMARY AND CONCLUSIONS}

Ground-penetrating radar was used to provide continuous profiles of the water table to help describe the ground-water-flow system in the towns of Brewster and Harwich, Massachusetts. Hydraulic heads from nine observation wells screened at various intervals below the water table, water-table altitudes from nine wells screened at the water table, and 35 water-table altitudes derived from GPR, were used to construct a single cross section showing components of groundwater flow in the top $100 \mathrm{ft}$ of the aquifer between Nantucket Sound and Cape Cod Bay. The direction of vertical flow components was downward in the central upland areas of the cross section, upward in the coastal areas, and variable, but generally upward about Long Pond near the center of the cross section.

More than $125 \mathrm{mi}$ of continuous GPR profiles of the subsurface were produced in the study. With a threeperson field crew, GPR data was collected at a rate of 2 to $5 \mathrm{mi} / \mathrm{h}$. For water-table profiling, GPR data was corrected for topographic variability by leveling land surface altitude. Leveling took three to five times as long as GPR data collection, which added significantly to the time required to complete calculation of the water-table altitude.

Penetration of the GPR signal ranged from less than $3 \mathrm{ft}$ in the fine-grained sediments in lake-deposit areas, to greater than $95 \mathrm{ft}$ in the coarse-grained sediments of the outwash plain. The clay found in the fine-grained sediments of the lake-deposit areas severely limited the depth of penetration of the radar signal.

Seventy of the 120 GPR surveys made during the study indicated the presence of water-table reflectors that were easily identified on the graphic record. Of the remaining 50 surveys, only 5 did not indicate the presence of water-table reflectors on the graphic record. All of these five were made in the area underlain by lake-deposits where clays significantly reduced the amount of penetration of the GPR signal, and a large capillary fringe did not provide a strong saturatedzone reflector. The remaining surveys produced records in which discontinuous saturated zone reflectors were easily identified.

The velocity of GPR signals in unsaturated materials were calculated on the basis of known water levels from 21 ponds and 64 wells. The calculated velocities ranged from 0.33 to $0.51 \mathrm{ft} / \mathrm{ns}$ and averaged $0.45 \mathrm{ft} / \mathrm{ns}$. The actual GPR signal velocity varied because of differences in subsurface moisture content and lithology. The average velocity of the GPR signal for the study area $(0.45 \mathrm{ft} / \mathrm{ns})$ was used to interpret water-table altitudes along each GPR survey line. Comparison of actual and GPR-derived values of depth to water below land surface at 85 calibration tests indicated an average error of about 7 percent $(1.8 \mathrm{ft}$ ) when using this average velocity. The accuracy of GPR-derived depth-to-water estimates depends largely on the moisture content of soils and accurate measurements of travel time of the radar signal.

Water-table altitudes derived using GPR and seismic refraction methods were compared with each other and with measured water levels in observation wells. The results indicated a good agreement between each geophysically-determined water-table altitude and the measured altitudes for selected wells.

A water-table map with 2 -ft contour intervals was constructed for the entire study area on the basis of water-level measurements at 75 observation wells, at 36 ponds, and at Herring River, and on 180 water levels derived from 38 GPR surveys. The GPR was particularly useful for determining water-table gradients between areas with known water levels.

The GPR surveys did not identify drawdowns of the water table caused by pumping at wells. Attempts were made to prepare detailed water-table maps of the zones of contribution to public-supply wells in Brewster and Harwich, Massachusetts. Because pumping rates at the public-supply wells and moisture content of the unsaturated zone were variable, water-table profiles derived by GPR indicate that the water-table altitudes differed considerably from station to station, and were impossible to contour. The GPR surveys around the supply wells did, however, provide an indication of the relative water-table gradient about the pumped wells. Drawdown of the water table 


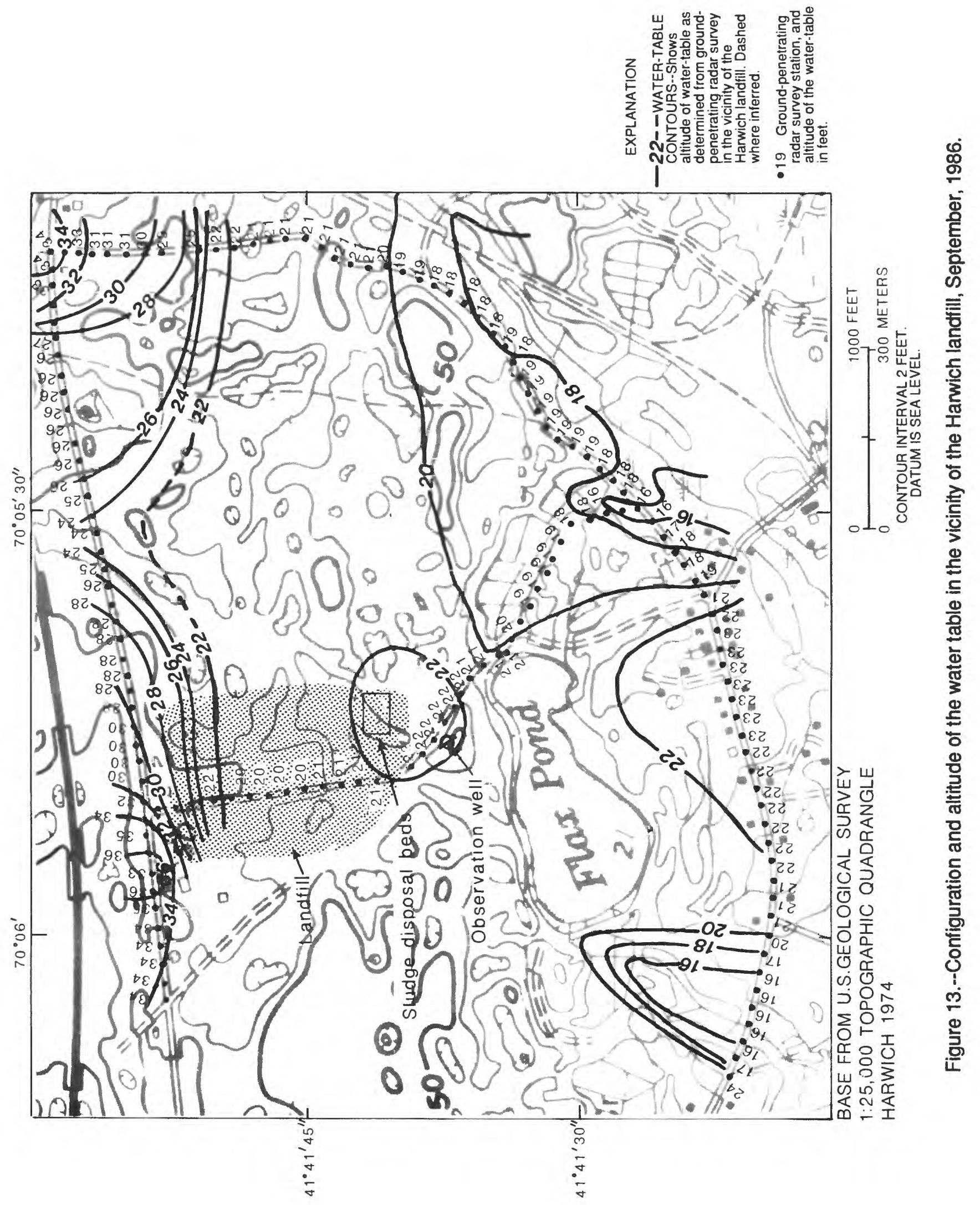


caused by any single well or group of wells was not apparent in any of the GPR profiles.

Horizontal directions of ground-water flow could be estimated by GPR surveys at waste-disposal areas. A water-table map was constructed for a $1-\mathrm{mi}^{2}$ area about the Harwich landfill, on the basis of GPR-derived altitudes. GPR profiles showed the presence of a water-table mound in the vicinity of the septage disposal beds between the landfill and Flax Pond in the fall of 1986, but profiles repeated in 1987 did not show a mound. The GPR data also showed the presence of a steep hydraulic gradient along the stream southwest of Flax Pond.

\section{REFERENCES CITED}

Bowders, J. J., Jr., Koerner, R. M., and Lord, A. E., Jr., 1983, Potential use of GPR in hazardous waste monitoring in unsaturated soils, Mercer, J. W., Rao, P. S. C., and Marine, I. W., Eds., in Proceedings of American Geophysical Union Symposium on Role of Unsaturated Zone in Radioactive and Hazardous Waste Disposal: Ann Arbor, Michigan, Ann Arbor Science Co., p. 179-193.

Collins, M. E., and Doolittle,J. A., 1987, Using groundpenetrating radar to study soil microvariability: Soil Science Society of America Journal, v. 51, p. 491-493.

Davis, J.L., Killey, R.W.D., Annan, A.P., and Vaughan, C., 1984, Surface and borehole ground-penetrating radar surveys for mapping geological structure, in NWWA/EPA Conference on Surface and Borehole Geophysical Methods in Ground Water Investigations: National Water Well Association, Worthington, Ohio, p. 681-710.

Dobrin, M.B., 1976, Introduction to geophysical prospecting (3d ed.): New York, McGraw-Hill, 630 p.

Frimpter, M.H., 1973, Ground-water management Cape Cod, Martha's Vineyard, and Nantucket, Massachusetts: U.S. Geological Survey OpenFile Report, 53 p.

Frimpter, M.H., and Gay, F. B., 1979, Chemical quality of ground water on Cape Cod, Massachusetts: U.S. Geological Survey Water-Resources Investigations 79-65, $11 \mathrm{p}$.
Guswa, J. H., and LeBlanc, D.R., 1985, Digital models of ground-water flow in the Cape Cod aquifer system, Massachusetts: U.S. Geological Survey Water-Supply Paper 2209, 112 p.

Horsley, S.W., 1982, Hazardous materials on Cape Cod: A spill response guide: Cape Cod Planning and Economic Development Commission, p. 7072.

Jesch, R.L., 1978, Dielectric measurements of five different soil textural types as functions of frequency and moisture content: U.S. Department of Commerce, National Bureau of Standards Report NBSIR 78-896, $22 \mathrm{p}$.

Johnson, D.G., and Davis, N.M., 1988, Water-table map of Brewster and Harwich, Massachusetts: September 21 to October 22, 1987: U.S. Geological Survey Open-File Report 88-330, 1 sheet, scale $1: 25,000$.

LeBlanc, D.R., Guswa, J. H., Frimpter, M.H., and Londquist, C. J., 1986, Ground-water resources of Cape Cod, Massachusetts: U.S. Geological Survey Hydrologic Investigations Atlas HA-692, 4 sheets, scale $1: 48,000$.

Letty, D. F., 1984, Ground-water and pond levels, Cape Cod, Massachusetts, 1950-82: U.S. Geological Survey Open-File Report 84-719, 81 p.

Oldale, R.N., 1969, Seismic investigations on Cape Cod, Martha's Vineyard, and Nantucket, Massachusetts, and a topographic map of the basement surface from Cape Cod Bay to the Islands: U.S. Geological Survey Professional Paper 650-B, p. B122-B127.

Oldale, R.N., 1981, Geologic history of Cape Cod, Massachusetts: U.S. Geological Survey, 23 p.

Oldale, R.N., and Tuttle, C.R., 1965, Seismic investigations in Harwich and Dennis Quadrangles, Cape Cod, Massachusetts: U.S. Geological Survey Professional Paper 525-D, p. D101-D105.

Olhoeft, G.R.., 1984, Applications and limitations of ground-penetrating radar: Society of Exploration Geophysicists 53rd Annual Meeting, Program and Abstracts, p. 147-148.

1987, Electrical properties from $10^{-3}$ to $10^{9} \mathrm{~Hz}$, Physics and chemistry: in Physics and Chemistry of Porous Media II, AIP Conference Proceedings 154, J.R. Banavar, J. Koplik, and K.W. 
Winkler, N.Y., American Institute of Physics, p. 281-298.

Olhoeft, G.R., and Capron, D.E., [in press] The use of geophysics in hazardous-waste investigations: U.S. Geological Survey Water-Resources Investigations Report.

Pakiser, L.C., and Black, R.A., 1957, Exploring for ancient channels with the refraction seismograph: Geophysics, v. 22, p. 32-47.

Scott, J.H., 1977, SIPT-A seismic refraction inverse modeling program for timeshare terminal computer systems: U.S. Geological Survey Open-File Report 77-365, $35 \mathrm{p}$.

Scott, J.H., Tibbetts, B.L., and Bordick, R.G., 1972, Computer analysis of seismic refraction data: U.S. Department of the Interior, Bureau of Mines Report of Investigations RI 7595, $295 \mathrm{p}$.

Shih, S.F., Doolittle, J.A., Myrhe, D.L., and Schellentrager, G.W., 1986, Using radar for ground water investigations: Journal of Irrigation and Drainage Engineering, v. 112, no. 2, p. $110-118$.

Thornthwaite, C.W., and Mather, J. R., 1957, Instructions and tables for computing potential evapotranspiration and the water balance, in Publications in Climatology: Drexel Institute of Technology, Centerton, New Jersey, v. 10, no. 3, p. 185-311.

Ulriksen, P., 1982, Application of impulse radar to civil engineering: Lund University of Technology, Lund, Sweden, 179 p.

Wright, D.L.., Olhoeft, G.R.., and Watts, R. D., 1984, Ground-penetrating radar studies on Cape Cod, in Nielson, D. M., and Curl, M., Eds., NWWA/EPA Conference on Surface and Borehole Geophysical Methods in Ground-Water Investigations: National Water Well Association, Worthington, Ohio, p. 666-680. 